\title{
The CD73/Ado System-A New Player in RT Induced Adverse Late Effects
}

\author{
Simone de Leve, Florian Wirsdörfer and Verena Jendrossek *(D) \\ Institute of Cell Biology (Cancer Research), University Hospital Essen, 45122 Essen, Germany; \\ simone.deleve@uk-essen.de (S.d.L.); florian.wirsdoerfer@uk-essen.de (F.W.) \\ * Correspondence: verena.jendrossek@uni-due.de; Tel.: +49-201-72333380; Fax: +49-201-7235904
}

Received: 29 September 2019; Accepted: 12 October 2019; Published: 16 October 2019

check for updates

\begin{abstract}
Radiotherapy (RT) is a central component of standard treatment for many cancer patients. $\mathrm{RT}$ alone or in multimodal treatment strategies has a documented contribution to enhanced local control and overall survival of cancer patients, and cancer cure. Clinical RT aims at maximizing tumor control, while minimizing the risk for RT-induced adverse late effects. However, acute and late toxicities of IR in normal tissues are still important biological barriers to successful RT: While curative RT may not be tolerable, sub-optimal tolerable RT doses will lead to fatal outcomes by local recurrence or metastatic disease, even when accepting adverse normal tissue effects that decrease the quality of life of irradiated cancer patients. Technical improvements in treatment planning and the increasing use of particle therapy have allowed for a more accurate delivery of IR to the tumor volume and have thereby helped to improve the safety profile of RT for many solid tumors. With these technical and physical strategies reaching their natural limits, current research for improving the therapeutic gain of RT focuses on innovative biological concepts that either selectively limit the adverse effects of RT in normal tissues without protecting the tumor or specifically increase the radiosensitivity of the tumor tissue without enhancing the risk of normal tissue complications. The biology-based optimization of RT requires the identification of biological factors that are linked to differential radiosensitivity of normal or tumor tissues, and are amenable to therapeutic targeting. Extracellular adenosine is an endogenous mediator critical to the maintenance of homeostasis in various tissues. Adenosine is either released from stressed or injured cells or generated from extracellular adenine nucleotides by the concerted action of the ectoenzymes ectoapyrase (CD39) and $5^{\prime}$ ectonucleotidase (NT5E, CD73) that catabolize ATP to adenosine. Recent work revealed a role of the immunoregulatory CD73/adenosine system in radiation-induced fibrotic disease in normal tissues suggesting a potential use as novel therapeutic target for normal tissue protection. The present review summarizes relevant findings on the pathologic roles of CD73 and adenosine in radiation-induced fibrosis in different organs (lung, skin, gut, and kidney) that have been obtained in preclinical models and proposes a refined model of radiation-induced normal tissue toxicity including the disease-promoting effects of radiation-induced activation of CD73/adenosine signaling in the irradiated tissue environment. However, expression and activity of the CD73/adenosine system in the tumor environment has also been linked to increased tumor growth and tumor immune escape, at least in preclinical models. Therefore, we will discuss the use of pharmacologic inhibition of CD73/adenosine-signaling as a promising strategy for improving the therapeutic gain of RT by targeting both, malignant tumor growth and adverse late effects of RT with a focus on fibrotic disease. The consideration of the therapeutic window is particularly important in view of the increasing use of RT in combination with various molecularly targeted agents and immunotherapy to enhance the tumor radiation response, as such combinations may result in increased or novel toxicities, as well as the increasing number of cancer survivors.
\end{abstract}

Keywords: purinergic signaling; radiotherapy; normal tissue toxicity; pneumonitis; fibrosis; adenosine; tumor microenvironment; therapeutic window 


\section{Background}

Current calculations from the National Cancer Institute estimate that $38.4 \%$ of the human population worldwide will be diagnosed with cancer during their lifetime and that until 2030, the number of newly diagnosed cancer patients per year will rise to 23.6 [1]. Despite constant improvements in cancer treatment and decreasing death rates, cancer is still a life-threatening disease: 9.6 million cancer patients worldwide died from their disease in 2018, and $20.3 \%$ of these deaths occurred in Europe [2] highlighting the need for further improvements in cancer therapy.

Together with surgery and chemotherapy radiotherapy (RT) belongs to the current three standard treatment options for cancer patients. More than $60 \%$ of all cancer patients receive RT at least once during the course of their disease with curative or palliative intent [3-5]. Though RT has a documented contribution to enhanced local control and overall survival of cancer patients and cancer cure, patient outcome needs to be further improved for common forms of cancer with high loco-regional failure-rates or frequent development of metastases. Avoiding adverse effects in normal tissues is another major challenge in clinical RT, particularly in tumors growing adjacent to critical structures or within tissues or organs with pronounced radiation sensitivity.

In fact, acute and late toxicity to normal tissues at risk is an important biological barrier to be successful in RT: normal tissue toxicity precludes the use of curative RT doses and may thus result in suboptimal local tumor control or metastatic disease even when accepting side-effects that decrease quality of life $[3,6,7]$. Furthermore, normal tissue toxicity limits therapy intensification efforts for many locally advanced tumors through the combination RT with cytotoxic chemotherapy [8-10]. Documented toxic effects of RT include for example acute toxicity to the hematopoietic system, gastrointestinal tract, skin, or mucosal tissues (mucositis, pneumonitis); acute toxic effects are mostly reversible, but can be life-threatening when they are severe. Instead, long-term adverse effects such as disturbance of proper bone growth, fibrotic lung disease, cardiotoxicity, cognitive impairment, as well as induction of secondary tumors are considered to be mostly irreversible and progressive, and can thereby strongly impact the quality of life of the patients, as well as patient survival.

A certain RT dose is tolerable if the probability of an effective tumor response is higher than the probability of significant adverse effects to critical normal tissues within or adjacent to the radiation field. Improvements in the therapeutic gain of RT, can thus be obtained by enhancing the precision of RT delivery, as well as from biological strategies interfering with molecular or cellular mechanisms driving tumor or normal tissue responses to RT. Herein, RT practice has largely benefited from technical improvements in treatment planning, e.g., stereotactic radiotherapy or intensity-modulated radiation therapy, that increased accuracy of dose delivery while reducing normal tissues exposure. Furthermore, therapy approaches with charged particles (mainly protons, and carbon ions) deliver only a limited amount of energy to superficial tissues while allowing the deposition of high radiation doses with high accuracy to deep-seated tumors [11-13]. Advances in dose delivery to improve tumor killing with minimal toxicity have also been described using ultrahigh dose-rate (FLASH) irradiation with rates above 100Gy/sec [14-17]. For example, a recent case report revealed promising results regarding safety and outcome both on normal tissue and tumor [18]. Clinical translation of emerging FLASH radiotherapy has been discussed in recent reviews highlighting the need of further studies and technical improvements in this aspiring research field $[19,20]$. However, some patients still suffer from adverse effects highlighting the high medical need for further improvements.

Beyond dose-limiting normal tissue toxicity, further biological factors limit the efficacy of RT and thereby decrease the life quality of the treated patients [11]: These include amongst others intrinsic and environment-induced radioresistance of tumor cells, individual heterogeneity in tumor and normal tissue responses to IR, phenotypic plasticity of cancer cells, as well as enrichment in radioresistant cancer stem cells [21-29]. Further improvements in the outcome of patients with locally advanced 
tumors are therefore expected from treatment protocols combining precision RT with mechanism-based drug-therapy $[5,30]$. Recent progress in immunotherapy and new insight into the biologic effects of IR suggest that the combination of highly conformal RT with immunotherapy may also be suited to further improve therapy outcome [31,32].

However, preclinical and clinical investigations demonstrate that toxicity rates can increase or new toxicities can occur when using molecularly targeted drugs such as angiogenesis inhibitors, DNA repair pathway blockers or immune checkpoint inhibitors in combination with RT as part of a biologically optimized RT [11,33-36]. Thus, it will be favorable to combine RT with mechanism-based drug therapy suited to attenuate or mitigate adverse late effects or protect normal tissues from the toxic effects of RT if we aim to design effective strategies for improving the therapeutic gain of RT and enhance cure rates in combinatorial approaches [37].

Exposure to IR damages cellular macromolecules, e.g., proteins, lipids, as well as nuclear and mitochondrial DNA, either directly or indirectly though induction of reactive oxygen species. Induction of double strand breaks (DSB) in genomic DNA is considered as most lethal event; therefore, it is not surprising that cells have developed a multifaceted DNA damage response (DDR) that is initiated within minutes upon irradiation and reflects the severity and the biology of the induced DNA damage (for detailed review of the DDR please refer to [38-40]).

Local irradiation of normal tissues usually hits several different resident cell types, e.g., epithelial cells, endothelial cells as well as tissue stem cells, so that the resulting response will reflect the integration of the DDR of the affected cell types. The resulting cellular responses to IR initiate a complex cascade of events that can cause acute toxicity, chronic adverse effects, or both [41-44].

Cellular responses to RT-induced damage or cell death trigger a cascade of events that leads within days or weeks to activation of innate and adaptive immune responses, pronounced inflammation (e.g., skin toxicity, mucositis, pneumonitis), vascular damage or dysfunction, or after months to excessive deposition of extracellular matrix molecules and tissue scarring (fibrosis) with potential impact on the quality of life and patient survival $[45,46]$. Indeed, deregulated cytokine production and infiltration of immune cells are frequent pathologic findings in irradiated tissues and are also observed in murine models [45,47-55]. Analyses in preclinical models and patients' samples demonstrate a complex tissue response with multiple interactions between resident cells, stromal factors such as vascular cells, stromal fibroblasts and tissue stem cells, and infiltrating immune cells $[46,56,57]$.

Though RT exerts early immunosuppressive effects by efficient killing of immune cells within the radiation field [58], acute tissue responses to RT clearly involve activation of various aspects of innate and adaptive immune responses that have been extensively reviewed elsewhere [59-66]. Importantly, immune responses to RT have a dual face as they may induce the accumulation of immunoregulatory or even immunosuppressive mediators and immune cell types with tumor-promoting characteristics [42,67-69] that are reminiscent of processes involved in tumor immune escape [70-72]. Adverse inflammatory processes in irradiated normal tissues frequently respond to steroid therapy. Nevertheless, it is still controversial if infiltrating immune cells and endogenous regulators of tissue inflammation and inflammatory resolution directly contribute to the pathophysiology of RT-induced adverse late effects or only modulate disease progression [73].

Herein, recent reports including own findings highlight a pathogenic role of the immunoregulatory ecto-5'-nucleotidase (NT5E, CD73)/adenosine system in radiation-induced adverse late effects [68,74,75]. Generally, adenosinergic signaling is an essential endogenous regulator of tissue homeostasis that is involved in maintenance and reconstitution of tissue homeostasis upon stress or injury [76-79].

Thus far, there are only limited investigations about the role of CD73 and adenosine in RT-induced normal tissue toxicity. Here, we summarize current knowledge on the role of CD73 and adenosine in promoting radiation-induced normal tissue toxicity with a special focus on its general and tissue-specific contribution to IR-induced fibrotic disease. We will also highlight pathologic aspects of CD73/adenosine signaling in malignant tumors and discuss the potential benefit of CD73/adenosine targeting strategies for improving the therapeutic gain of RT. 


\section{Purinergic Signaling and Tissue Homeostasis}

CD73 and adenosine are critical endogenous regulators of tissue homeostasis balancing tissue inflammation and repair processes in diverse pathological situations and preventing autoimmunity [78,80-82]. Upon controlled (Pannexin 1 channel) or uncontrolled release into the extracellular room ATP acts as a danger signal that initiates pro-inflammatory signaling cascades through binding to P2 receptors (the ionotropic P2X receptors or the metabotropic P2Y receptors) [83-87]. Extracellular ATP is usually rapidly converted to ADP and AMP via membrane bound ectoenzymes of the ectonucleoside triphosphate diphosphohydrolases (ENTPDases) or alternatively nucleotide pyrophosphatase/phosphodiesterases (NPPases) that thereby terminate ATP signaling through P2X or PTY nucleotide receptors $[80,82,88]$.

CD39 (ectonucleoside triphosphate diphosphohydrolase1, ENTPD1) is mainly expressed on the surface of various immune cells but also on epithelial, endothelial cells and specific subpopulations of fibroblasts as described elsewhere [89-94]. CD39 is responsible for ATP degradation into ADP and further into AMP that will fuel CD73 activity and the generation of adenosine (Figure 1). CD73 acts in concert with CD39 to generate adenosine from extracellular AMP [81,95]. CD73 is found on the surface of various cell types, particularly endothelial cells [84] and immune cells, e.g., conventional CD4 and CD8 T cells, murine regulatory T cells $\left(\mathrm{T}_{\text {reg }}\right)$, regulatory $\mathrm{B}$ cells $\left(\mathrm{B}_{\text {reg }}\right)$ and macrophages, but also mesenchymal stromal cells (MSC) and epithelial cells from various healthy tissues [82,91,92,96-102]. As mentioned above several murine immune cells as well as resident cells express CD39 and CD73. Of note, the expression patterns of CD39 and CD73 differ between mice and humans as summarized by Allard and colleagues in detail [103]. Briefly, in human peripheral blood CD39 is constitutively expressed on $20-30 \%$ of $\mathrm{CD}^{+} \mathrm{T}$ cells (including memory $\mathrm{T}$ cells and $\mathrm{T}_{\mathrm{reg}}$ ), $<5 \%$ of $\mathrm{CD} 8^{+} \mathrm{T}$ cells, $2-5 \%$ of NK cells, $>90 \%$ of B cells and $>90 \%$ of monocytes. The expression of CD73 in human peripheral blood is $10 \%$ of $\mathrm{CD}^{+} \mathrm{T}$ cells, $50 \%$ of $\mathrm{CD} 8^{+} \mathrm{T}$ cells, $75 \%$ of $\mathrm{B}$ cells and $2-5 \%$ of NK cells.

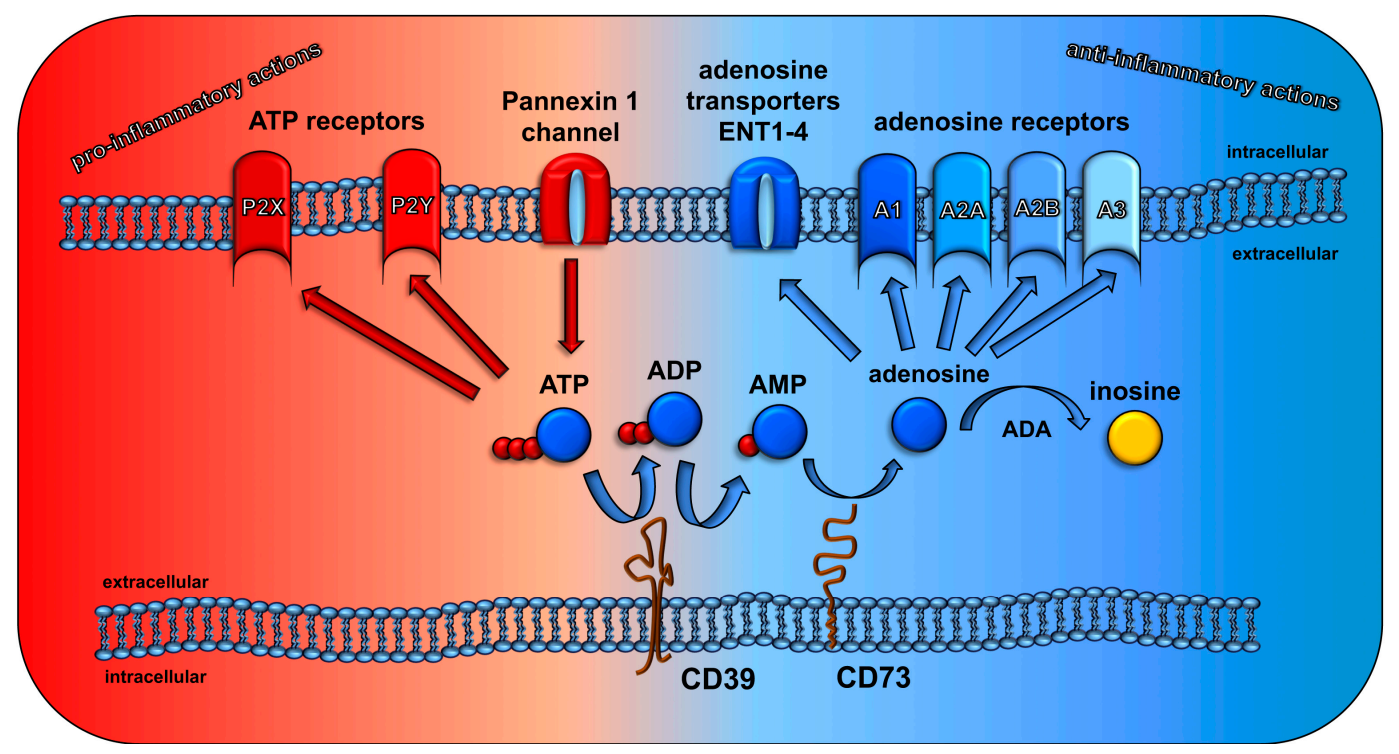

Figure 1. Purinergic Signaling. ATP can be released uncontrolled into the extracellular room by damaged or dead cells or actively via Pannexin1 channels. If ATP is released into the extracellular room multiple processes can take place. It can bind to different ATP receptors (P2 receptors) and in consequence pro-inflammatory signaling cascades will be induced. On the other hand, extracellular ATP can be rapidly converted to adenosine via two membrane bound ecto-nucleotidases CD39 and CD73. Binding to one of four different receptors adenosine exerts mostly immunoregulatory effects. Alternatively, extracellular adenosine can be shuttled into target cells via adenosine transporters or is converted via the adenosine deaminase to inosine. 
The major discrepancy between mice and humans is that in humans, only $1-5 \%$ of $\mathrm{T}_{\text {reg }}$ express surface-bound CD73. Compared to conventional $\mathrm{T}$ cells, human $\mathrm{T}_{\text {reg }}$ show however enriched expression (75\%) of intracellular CD73 [104]. Moreover, several recent studies highlight that human $\mathrm{T}_{\text {reg }}$ do not co-express CD39 and CD73 on their surface but instead need to cooperate with other cells expressing CD73, to generate adenosine and mediate immunosuppression [105-107]. Studies investigating the expression of CD73 on T cells subsets in humans are rare, but Doherty and colleagues suggest a potential link between a Th17 profile and CD73 expression on memory CD4 ${ }^{+} \mathrm{T}$ cells in patients with inflammatory bowel disease [108]. Similar results were obtained by Schuler and co-workers demonstrating that human $\mathrm{CD} 4^{+} \mathrm{CD} 3^{+} \mathrm{T}$ cells belong to a subset of $\mathrm{T}$ cells expressing the memory marker CD45RO as well as the activation marker CD26 [109]. In line with the findings described above, Gourdin et al. reported, that CD73 expression defined a subset of polyfunctional Th1.17 cells that infiltrated breast and ovarian tumors. Moreover, $\mathrm{CD} 39^{+} \mathrm{T}_{\text {reg }}$ inhibited these $\mathrm{CD}^{+} 3^{+} \mathrm{Th} 1.17$ cells through cooperative degradation of ATP into adenosine [105]. Regarding the role of CD73 on CD8 ${ }^{+} \mathrm{T}$ cells Bono and coworkers reported that $\mathrm{CD} 73$ expression is high in naïve $\mathrm{CD} 8^{+} \mathrm{T}$ cells and is down-regulated upon activation. The authors suggest that CD73 down-regulation prevents autocrine adenosine signaling leading to successful differentiation into effector T cells [110]. As mentioned above, CD39 and CD73 are highly expressed on human B cells. Moreover, a study from Schena et al showed, that human B cells can store ATP in secretory vesicles that can be released upon B cell receptor activation. Furthermore, secreted ATP can be hydrolyzed into adenosine in an autocrine manner via CD39 and CD73 on these B cells which is important for class switch recombination [111]. The expression of CD73 on human macrophages can differ regarding the macrophage phenotype but is controversially discussed. Zanin et al. revealed that human pro-inflammatory M1 macrophages express lower levels of CD39 and CD73 compared to anti-inflammatory M2 macrophages [112]. In contrast, findings from Eichin and colleagues highlight that CD73 expression on human macrophages is induced after incubation with the LPS and TNF- $\alpha$, relevant for in vitro M1 macrophage polarization [113].

Thus, the distinct CD73 expression patterns on human immune cell subsets could impact the use of pharmacologic inhibition of CD73/adenosine signaling in human pathologies when compared to mice and these potential differences need further investigation.

In contrast to ATP, adenosine has mostly immuno-regulatory actions and triggers anti-inflammatory responses to limit inflammation-induced tissue damage [82,114]. Furthermore, CD73 and adenosine not only regulate the extravasation and function of diverse immune cells but also modulate epithelial cell behavior, vascular barrier function, and cell death [81,98,99,115-120]. The extracellular level of adenosine in normal tissues is usually low $(10-100 \mathrm{nM})[121,122]$ due to its very short half-life, as there exists a rapid cellular uptake by nucleoside transporters (equilibrative nucleoside transporters (ENT) and concentrative nucleoside transporters (CNT)) as well as extracellular or intracellular catabolic conversion by adenosine deaminase (ADA) or adenosine kinase (ADK) to inosine or AMP, respectively $[80,123]$. This strongly suggests that adenosine is a local modulator $[124,125]$ and might only act on cells in narrow environment near CD73 expressing cells. However, adenosine levels can rapidly increase in response to stress, hypoxia, or tissue injury either by direct release from damaged cells or through ATP/ADP catabolism by CD39 and CD73 reaching $\mu$ molar levels [121,122,126,127]. Using gradient ion-repair, reversed-phase HPLC at $254 \mathrm{~nm}$ [128], Vaupel and colleagues report tumor adenosine levels between 50 and $90 \mu \mathrm{M}$ in experimental DS-sarcoma in rats with rising concentrations in tumors with increasing hypoxic fractions or tumor volume, respectively [126,127]. Instead, Blay and colleagues report only mean steady state concentrations of $0.3-0.5 \mu \mathrm{M}$ adenosine in extracellular tumor fluid of murine and human colon (MCA-38, T-84, HT-29) and human A549 lung carcinomas in mice. These levels increased to 9-13 $\mu \mathrm{M}$ upon pharmacologic inhibition of adenosine degradation [122]. Finally, data from the Sitkovsky group [121] revealed higher levels of adenosine (about $0.2-1.3 \mu \mathrm{M}$ ) in MCA-205 fibrosarcoma in mice that were associated with pronounced hypoxia. Nevertheless, levels of extracellular adenosine in experimental tumors were always significantly higher than the adenosine levels in normal tissues that were in the $\mathrm{nM}$ range $(30 \pm 5 \mathrm{nM}$ or below $50 \mathrm{nM}[121,122]$ in skin tissue, as 
well as $100 \mathrm{nM}$ and $300 \mathrm{nM}$ in bronchoalveolar lavage fluid of murine lungs without or with exposure to whole thorax irradiation [74], respectively.

Extracellular adenosine can bind to and act through one of four different adenosine receptors (ADOR) A1, A2A, A2B and A3. Various immune cells among them neutrophils, monocytes, macrophages and lymphocytes express one or several of the 4 different G-protein-coupled adenosine receptors (ADORA1, ADORA2A, ADORA2B, ADORA3) on their cell surface [90,129-139]. While the activation of ADORA1 and ADORA3 lead to a decrease in intracellular cAMP concentrations as they are coupled to adenylate cyclase via the Gi/o subunits, coupling through the Gs subunit in ADORA2A and ADORA2B results in increased cAMP levels $[80,140]$. Under physiological conditions extracellular adenosine levels are below $1 \mu \mathrm{M}$ but high enough to activate ADORA1, ADORA2A and ADORA3 receptors. For the activation of ADORA2B adenosine levels higher than $10 \mu \mathrm{M}$ are needed, which are only achieved under stress conditions or pathophysiological conditions $[123,126]$.

Of note, while acute activation of CD73 and adenosine mostly exert tissue-protective effects, chronic extracellular accumulation of adenosine has widely been associated with pathologic processes, for example the development of tissue fibrosis e.g., in the skin, the lung, the liver, and the heart $[74,78,141-144]$.

\section{Modeling Radiation-Induced Adverse Late Effects In Vivo}

Various tissues (e.g., skin, gut, lung, kidney, liver) are sensitive to late adverse radiation effects such as vascular injury, inflammation, necrosis, fibrosis, and tissue dysfunction [145]. Particularly the progressive late adverse effects limit the total dose that can be safely applied during the treatment $[43,146]$.

Radiation-induced acute and chronic toxicities involve complex interactions between various types of resident cells, soluble mediators, infiltrating immune cells, and extracellular matrix molecules. Except from the type of tissue, the pathophysiology of the observed toxicities depends on additional factors, e.g., dose, treatment schedule, type and location of irradiation, as well as the functional state of the organ at risk at the time of irradiation [7]. In vitro model systems with co-culture of two or three different cell types have thus only limited power to predict the ongoing processes in the human body so that it is unavoidable to use in vivo model systems to study radiation-induced toxicities.

Different approaches are used to study radiation-induced adverse normal tissue effects in preclinical investigations in vivo: Many laboratories use preclinical rodent models (mostly mice or rats) to gain insight into potential effector cells and involved mediators [51-54,56,74,147-156]. Therefore, defined regions of the animals are exposed to photon irradiation using different sources (x-Rays, $\mathrm{Co}^{60}$, linear accelerator) and either single high dose irradiation or fractionated irradiation schemes [46,51,53,68,156-158]; further variations include the use of different radiation qualities, e.g., irradiation with photons versus protons $[159,160]$.

In some studies the antibiotic chemotherapeutic agent bleomycin is used as a surrogate for exposure to IR. Bleomycin induces single and double strand breaks in the DNA and is thus considered as useful to mimic irradiation-induced damage [161]. However, the instant action of IR and the protracted action of bleomycin will result in differences in the biology of the resulting DNA damage. Furthermore, bleomycin-induced normal tissue damage in vivo largely depends on the administration route and treatment schedule resulting in prominent differences in the tissue and immune responses induced by local versus systemic administration [162-164]. Therefore, we consider bleomycin as a surrogate with a limited translational capacity.

\section{Tissue-Specific Radiotoxicities}

Preclinical investigations of damage-induced sterile inflammation and fibrotic disease revealed that despite disease-specific mechanisms and pathologic drivers, the different pathologies share some common hallmarks reminiscent of wound healing processes [42,165]. Moreover, pulmonary fibrosis induced as an adverse late effect of RT, chemotherapy and some targeted agents has pathophysiologic features of idiopathic pulmonary fibrosis $[46,166]$. In vivo models of tissue fibrosis and the use of 
genetically modified mice have advanced our understanding of the underlying cellular and molecular mechanisms and helped to identify signaling molecules that participate in the pathogenesis of adverse late effects induced by exposure to IR in normal tissues, particularly the lung [45,46,56,57].

\subsection{Lung}

Patients suffering from malignant neoplasms in the thoracic region e.g., lung, breast or head, and neck cancer, as well as patients who receive total body irradiation (TBI) in conditioning regimens for stem cell or bone marrow transplantations may receive a certain radiation dose to the highly radiosensitive lung tissue [41].

Depending on the radiation dose and the irradiated lung volume receiving $\geq 20 \mathrm{~Gy}$, sensitive patients (5-20\%; $>30 \%$ for patients receiving TBI) typically develop pneumonitis at $2-6$ months whereas pulmonary fibrosis is observed 6 to 24 months after radiotherapy and may become chronic in patients with a larger irradiated lung volume [7,45]. Interestingly, early investigations reported a correlation of pneumonitis with the presence of increased levels of $\mathrm{CD}^{+} \mathrm{T}$-lymphocytes in the bronchioalveolar lavage fluid (BALF) of irradiated breast or lung cancer patients $[167,168]$ whereas the predictive value of cytokine plasma levels for radiation pneumonitis remains controversial $[169,170]$. The influx of immune cells e.g., lymphocytes, monocytes, neutrophils, and macrophages and associated changes in the cytokine and chemokine levels also characterizes this acute and chronic phases of lung injury in preclinical models $[47-49,51,56,68,169]$. Up to now, no causative but only symptomatic treatment with glucocorticoids is available, aimed at reducing inflammation and attenuating endothelial cell toxicity during the pneumonitic phase [171-173]. Other anti-inflammatory agents (Azathioprine and cyclosporine) were shown to effectively dampen the symptoms of pneumonitis and may be used if glucocorticoids are not suitable [171,174].

Also no causative therapy for prevention or treatment of radiation-induced lung fibrosis (RILF) is available in the clinic, though several approaches are under experimental investigation $[43,175,176]$.

Currently, researchers mostly use single high dose whole thorax or hemithorax irradiation of fibrosis-sensitive C57BL/6 mice to gain insight into disease pathogenesis as this strain is reminiscent of the clinical course of the disease and allows functional investigations about the role of identified factors using knockout strains with deficiency of the gene of interest [51,53,68,74,158,162]. However fibrosis sensitive C57BL/6 mice develop only mild pneumonitis; therefore, thoracic irradiation of C57L mice or regional irradiation of rat lungs might be better suited for investigations of pneumonitis and lung fibrosis, respectively $[56,158,162,177]$.

During recent years various mediators have been identified that participate in the pathogenesis of radiation-induced lung disease (RILD), such as transforming growth factor $\beta 1$ (TGF- $\beta$ ), platelet-derived growth factor (PDGF), connective tissue-derived growth factor, interleukin-6 (IL-6), IL-10, death receptor CD95 and its ligand, surfactant protein-A (SP-A) and SP-D, nuclear factor erythroid 2-related factor 2 (Nrf-2) but molecularly-targeted drugs did not make it yet to the clinics $[7,45,47,56,57,172,178-181]$.

\subsection{Skin}

Radiation-induced damage to the skin is a major problem in cancer therapy as $90-95 \%$ of all radiation-treated individuals develop some degree of skin toxicity within the irradiated field, at least when photon irradiation is used [182,183]. First signs of acute skin toxicity can usually be detected within the first four weeks after RT start. The effects are cumulative, and once manifested, stay throughout the treatment and last $2-4$ weeks after end of therapy [182,184,185]. Acute dermal radiation injury, also called radiation dermatitis, is characterized by erythema, dry/moist desquamation up to ulceration depending on its grade [184,185].

Instead, chronic radiation dermatitis observed months to years after RT is rare, and includes skin atrophy, over hypo-/hyperpigmentation, ulcerations and fibrosis $[183,184,186]$. Treatment of radiation-induced dermal injuries includes standard wound management and hygiene, adequate creams, and antibiotics [185]. Furthermore, treatment with pentoxifylline/alpha-Tocopherol and 
hyperbaric oxygen have shown promising results $[187,188]$. Tissue transfer to reconstruct irradiated areas has also shown good results as long as the patient's vessels are still accessible in the fibrotic tissue [188].

Interestingly, acute and chronic dermal injuries in irradiated patients are also characterized by immune cell infiltrates [182,189]. Furthermore, patient data revealed high levels of pro-inflammatory cytokines like TNF- $\alpha$, IL- 6 and IL-1, as well as pro-fibrotic drivers like TGF- $\beta$, PDGF and CTGF that are thought to promote pathogenesis by activating fibroblasts, inducing ECM secretion and recruitment of further leukocytes [183].

Various murine models exist to study radiation-induced skin toxicity that vary in dose, fractionation, as well as size and location of the irradiation field [147-149]. Single dose irradiation models are common and are used by several groups $[75,147-149,190]$. Of note, infiltration of immune cells is also a common feature of radiation-induced skin toxicity in mice though the infiltration-intensity is strain specific [149].

\subsection{Gut}

Radiation toxicity to the gastrointestinal tract is also highly dependent on the applied dose per fraction and the fractionation schedule as well as on the irradiated volume [191,192]. Up to $90 \%$ of the irradiated patients present changes in the bowl habits and 50\% of those experience a reduced quality of life after RT [193]. Early symptoms of radiation injury occur during or up to 90 days after therapy and include acute mucosal injury and inflammation [191]. Anti-inflammatory agents like five aminosalicylic acid (5-ASA) are suggested to reduce acute side effects of irradiation, but up to now a standardized use is not investigated sufficiently [194]. Acute tissue responses are furthermore characterized by the occurrence of growth factors, inflammatory mediators, and cytokine cascades [150,191]. In severe inflammation, mediators secreted from infiltrated monocytes, macrophages and granulocytes promote subsequent tissue damage, epithelial cell loss and degradation of ECM, which in turn may result in tissue fibrosis [195].

Chronic intestinal radiation injury occurs months or years following radiotherapy and is accompanied by side effects like fibrosis, vascular sclerosis, diarrhea, abdominal or bottom pain, fecal incontinence and intestinal blood loss $[191,193,196]$. There is one study showing a protection of chronic irradiation side effects using antioxidants like vitamin $\mathrm{E}$ and $\mathrm{C}$, whereas investigations using Amifostine or Sucralfate still lack sound data to recommend usage in the clinical routines [194]. Nevertheless, several agents with assumed protective action are under current pre-clinical investigations.

Animal models to study the pathology of radiation-induced intestinal injury range from whole body or abdominal irradiation models up to irradiation models that include surgical exteriorization of the small intestine or models where only parts of the intestine can be irradiated $[150,151,197]$. In addition, a recent report introduced an image-guided murine model, which better simulates the situation observed in the clinics and is such suitable for the analysis of potential radioprotectors [150].

\subsection{Kidney}

Radiation-induced damage to the kidneys can also be subdivided into acute and chronic nephropathy, where acute injuries are detected within three months after RT and chronic side effects are usually detected from 18 months following therapy [198,199]. Characteristic symptoms of renal radiation injury are reduced glomerular filtration rate, anemia, hypertension, edema and renal failure [198-200]. The kidneys are extremely sensitive to irradiation as it was shown that doses of 4 Gy can cause renal injury, thereby limiting the applied dose for example for TBI $[198,200]$.

So far, only limited preclinical investigations about radiation-induced kidney toxicity are available. Due to the importance of renal toxicity in nuclear medicine applications most preclinical studies focus on toxicity of radiopharmaceuticals like ${ }^{131} \mathrm{I},{ }^{211} \mathrm{At}$, and ${ }^{177} \mathrm{Lu}$ on normal renal tissues [201-205]. Furthermore, some preclinical studies used irradiation models with X-rays, e.g., exposure of the right kidney to a single dose of 8-10 Gy [206]. More common are experiments with exposure to TBI where 
the normal tissue response of the kidneys is studied among other organs [207,208]. So far, no data are available about the importance of radiation-induced immune changes in kidney injury. However, in the model of unilateral ureteral obstruction (UUO)-induced renal fibrosis it has been reported that macrophages infiltrate the injured kidney and change their phenotype from pro-inflammatory during the acute damage to anti-inflammatory during fibrosis development [209,210]. This suggests, that damage-induced changes in the immune cell phenotype, particularly macrophages, may well play a role in damage-induced chronic kidney injury.

\section{Impact of the Adenosinergic Signaling Pathway in Radiation-Induced Normal Tissue Toxicity}

A causal link between chronic accumulation of adenosine, increased extracellular matrix deposition and fibrosis development had been nicely demonstrated in the skin and the lungs of mice with genetic deficiency of ADA as well as in the models using the DNA damaging drug bleomycin (BLM) [142,143,211-214]; for a review see [215,216]. ADA-deficient mice are characterized by chronically enhanced tissue adenosine levels and collagen content as well as increased levels of pro-fibrotic mediators like TGF- $\beta, \alpha$-SMA, CTGF and IL-13, and are therefore used as paradigm of adenosine-induced fibrosis in the lung and the skin. As mentioned above CD73 is expressed on several cell types, including cells that are responsible for matrix deposition like fibroblasts. Moreover, distinct subpopulations of fibroblasts express CD73. Nevertheless, fibroblasts and fibrocytes show differential expression of CD73; since CD73 is also a mesenchymal stem/stromal cell (MSC) marker present on fibroblast-like stromal cells it is difficult to identify and characterize these cells [217,218]. However, there is some evidence that CD73 expression levels may differ for the same cell type between the diverse tissues, e.g., for epithelial cells. CD73 is thought to be a key component of a protective pathway in epithelial barriers and critical to maintain epithelial barrier function [219]. For example, CD73 is expressed in epithelial cells of the gastrointestinal tract, the lung, the breast, the skin and the pancreas [220-222]. Herein, Thompson and coworkers demonstrated that the colonic intestinal epithelium expresses CD73 at higher levels than any other tissue, and that CD73 expression is limited to the apical surface of intestinal epithelial cells [118,220]. Moreover, there are differences in CD73 activity across different tissues, that can be ranked (highest to lowest) as follows: colon $>$ kidney $=$ brain $>$ liver $>$ lung $>$ heart $\gg$ muscle [81].

Vice-versa, the different tissues seem to vary with respect to the cell types and adenosine receptors that are primarily responsible for driving radiation-induced pathologies [215]: Shaikh and Cronstein nicely summarized the role of ADORA2A and ADORA2B in wound healing and fibrosis [216]. For example, ADORA2A had been identified as the major mediator of the pathologic action of adenosine in the skin [223-225]. In contrast, the pathogenic role of adenosine in chronic pulmonary and kidney disease had mostly been linked to ADORA2B, at least in preclinical murine models [143,226-228]. Moreover, an association between ADORA2B and chronic pulmonary/kidney disease was also found in patients [228,229]. Among the cells that are associated with the development of fibrosis, ADORs are widely expressed on fibroblasts and epithelial cells. Briefly in a murine dermal fibrosis model ADORA2A stimulated fibroblasts to produce collagens and to downregulate matrix metalloproteinases [230]. A study with rat cardiac fibroblast revealed expression of all ADORs on these cells [231], but only ADORA2A and ADORA2B appeared to be functionally relevant. Interestingly, using ADORA2A agonist or overexpression of ADORA2B in these cardiac fibroblasts basal collagen and protein synthesis were significantly decreased, highlighting an important role of ADOR signaling in regulating cardiac fibroblast collagen synthesis [231]. Regarding the expression of adenosine receptors on epithelial cells a study from Factor et al. revealed that epithelial cells type I and type II from murine lungs both express ADORA1 and ADORA2A. Of interest, the author demonstrated that both ADORA1 and ADORA2A were expressed 3-fold in apical membranes (towards the alveolar lumen) as compared with basolateral membranes of mouse lungs. The authors suggest that apical ADOR signaling regulates alveolar fluid clearance by adenosine in a paracrine/autocrine manner [232]. Nevertheless, the role of adenosine receptors on epithelial cells in fibrosis-associated disorders and radiation-induced normal tissue 
toxicity is still largely unclear, though the presence of ADORs on lung epithelial cells demonstrates a potential contribution.

ATP and adenosine are also tightly regulated in the CNS between neurons and astrocytes and are important for the regulation of the neuronal network [233]. ATP functions as a neurotransmitter and exerts largely excitatory effects whereas adenosine has a major regulatory, inhibitory function within the neuronal network $[233,234]$. In the context of the brain adenosine mostly exerts protective functions by regulating homeostatic and metabolic networks $[233,235]$. Under basal conditions availability of adenosine is tightly regulated by ADK [236]. While dynamic regulation of ADK gene expression is important to early postnatal brain development, loss or inhibition of ADK promotes pathologies in the brain, e.g., cancer and epilepsy [236-240]. It has been demonstrated that expression changes of ADK in response to brain injury and chemotherapy-induced neuropathic pain impact the levels of protective adenosine and thus disease severity [240-242].

Studies about radiation-induced tissue fibrosis analyzing the influence of the adenosinergic signaling in disease pathogenesis are rare. Nevertheless, some models exist and the results are summarized in the following paragraphs.

\subsection{CD73 and Radiation-Induced Lung-Disease}

So far, the role of CD73 and adenosine in RILD has only been studied in our laboratory. In our hands, loss of CD73/adenosine signaling protected mice exposed to a single high dose irradiation with 15 Gy from RT-induced early dysfunction of the blood/air barrier without affecting the infiltration of leukocytes. Furthermore, we demonstrated that $\mathrm{CD} 45^{+}$leukocytes and $\mathrm{CD} 45^{-}$resident lung cells express CD73; nevertheless, CD73 expression was enhanced in $\mathrm{CD}_{4} 5^{+}$leukocytes $\left(\mathrm{CD} 4^{+} \mathrm{T}\right.$ cells including $\mathrm{T}_{\text {reg, }}$, alveolar macrophages) particularly during the fibrotic phase and was associated with a progressive increase in adenosine levels in the bronchioalveolar lavage fluid. In CD45 resident lung cells CD73 expression was elevated particularly during the acute phase, indicating that adenosine conversion could be related to both, immune cells and to some extent to non-immune cells [74]. Definitely, further work is required to define the role of CD73 and of the disease-promoting ADORs on resident cells, immune cells or both for the tissue-, injury- and disease stage-dependent beneficial or adverse effects of adenosine in order to define biomarkers and optimal therapeutic targets. Genetic loss or pharmacologic inhibition of chronic accumulation of adenosine strongly attenuated fibrosis levels [74]. This was in contrast to findings obtained by others in preclinical models studying the role of the CD73/adenosine system in pneumonitis and transient fibrosis induced by acute intratracheal injection of bleomycin in mice. In this acute damage model, loss of CD73 in $\mathrm{CD}^{-/-}$mice exacerbated bleomycin-induced pneumonitis and fibrosis, revealing protective roles of CD73 and extracellular adenosine [142]. As opposed to this, inhibition of the low-affinity ADORA2B receptor attenuated pulmonary fibrosis induced by chronic treatment with bleomycin by repeated intraperitoneal injections $[143,227]$ which is consistent with our findings $[74,243]$. Altogether these observations suggest that the beneficial or disease-promoting effects of adenosine vary depending on the tissue, the type of injury and acute vs. chronic disease stages and may be dictated by the local expression of CD73, specific adenosine receptors, or both and this might be related to local levels of tissue hypoxia $[126,143,215,244]$.

So far, the adenosine receptor responsible for mediating disease-promoting adenosine effects in radiation-induced pulmonary fibrosis remains elusive. In own unpublished work the expression of ADORA2B was substantially higher in the un-irradiated normal lung tissue when compared to the expression levels of ADORA1, ADORA2A, and ADORA3. Furthermore, thoracic irradiation led to a significant increase in the expression of ADORA2B in C57BL/6 mice when tissue levels were determined during the fibrotic phase; instead the expression level of ADORA2B was not increased in the lung tissue of irradiated CD73 knockout mice [243]. The late appearance of the adverse adenosine effects could be due to the facts that (i) the ADORA2B is a low-affinity receptor so that higher adenosine concentrations are needed to induce significant signaling via ADORA2B and (ii) that the adenosine 
levels were only significantly increased as of 16 weeks after irradiation so that the pathogenic effects may only be initiated at this late time-point.

We propose that activation of CD73/adenosine signaling amplifies pro-fibrotic signaling in the irradiated lung environment ([243] and see below) Moreover, in the model of radiation-induced pneumopathy the adverse chronic effects of CD73 and adenosine seem to predominate and may explain that treatment with inhibitory CD73 antibodies or inhibitors of adenosine signaling were beneficial [74].

\subsection{CD73 and Radiation-Induced Skin Disease}

So far, most data on the role of CD73 in dermal fibrosis originate from studies using the radiomimetic drug bleomycin or mice deficient in the adenosine-degrading enzyme ADA as follows: Loss of CD39 and/or CD73 or inhibition of ATP-release into the extracellular space strongly reduced or even prevented the development of bleomycin-induced skin fibrosis [224,245]. In line with these findings, mice deficient for ADORA2A or treated with an ADORA2A antagonist were protected from bleomycin-induced dermal fibrosis and had reduced numbers of fibrocytes in the fibrotic tissue $[230,246]$. Signaling via ADORA2A was recently linked to activation of the $W n t / \beta$-catenin pathway-a known contributor to tissue fibrosis [247]. Of note, pharmacologic blockade of the ADORA2A also reduced pro-fibrotic mediators in ADA-deficient mice with chronically enhanced tissue adenosine levels and protected them from skin fibrosis [223]. Others observed a pathogenic role of ADORA2B in progression of adenosine-driven skin fibrosis [248]: ADORA2B expression was increased in fibrotic skin samples; pharmacologic blockade of ADORA2B attenuated bleomycin-induced skin fibrosis and this was associated with reduced levels of fibronectin, $\alpha-\mathrm{SMA}^{+}$myofibroblasts, hyaluronic acid and alternatively activated macrophages [248].

To our best knowledge there is only one study investigating the role of adenosinergic signaling in radiation-induced dermal fibrosis. In this model inhibition or deletion of ADORA2A attenuated dermal fibrosis development upon single high dose irradiation (40 Gy) and this was associated with reduced infiltration of T-cells, a typical feature of radiation-induced skin injury [75]. In contrast to our observations in radiation-induced pulmonary fibrosis, macrophages did not play a pathogenic role in this model, highlighting tissue-specific effects of CD73, adenosine and specific immune cells in the irradiated tissue environment with impact on radiation-induced adverse late effects.

\subsection{Gut}

So far, potential beneficial or adverse effects of CD73 and adenosine on the adverse effects of RT in the gut have not yet been studied. However, some reports point to tissue-protective effects of CD73/adenosine signaling in acute inflammatory diseases of the gastrointestinal tract by suppressing pro-inflammatory processes $[79,249,250]$. This is reminiscent of the above-mentioned tissue-protective effects of CD73 and adenosine in acute bleomycin-induced lung injury [142] and other models of acute tissue damage $[81,118,251,252]$. However these beneficial effects of CD73/adenosine signaling in the gastrointestinal tract were not only observed in diseases associated with acute inflammation in the gut but also in chronic colitis: For example, treatment of rabbits with an ADORA2A agonist significantly reduced inflammation in acute inflammatory bowel disease and further suppressed inflammatory infiltration in chronic colitis, thus preventing mortality [253]. Moreover, these beneficial effects were also induced by ADORA3 activation and led to inhibition of DSS-induced colitis in mice [254]. This protective effect of adenosine receptors in gastrointestinal inflammation was also revealed using adenosine receptor knockout mice $[249,255]$.

These findings suggest that CD73 and adenosine have a protective function in both, acute and chronic inflammatory disease in the gastrointestinal tract, at least in a murine model of Crohns disease.

\subsection{Kidney}

Several studies investigating acute renal damage reported protective effects of CD73 and adenosine [256-259]. Furthermore ADORA2A on bone marrow derived cells protected mice from acute 
ischemia/reperfusion damage [260]. On the other hand, CD73 and ADORA2B were upregulated in patients and murine studies of chronic kidney injury. Here, CD73 contributed to disease progression through exaggerated production of extracellular adenosine [228].

Again, to our best knowledge there are no published data available investigating the role of the adenosinergic signaling in radiation-induced renal injury.

\subsection{CNS}

Adenosine is an endogenous neuroprotectant and modulator of cognition, and dysregulation of adenosine has been linked to radiation-induced cognitive dysfunction $[238,239]$. Astrocytes control the availability of adenosine though ADK-dependent metabolic clearance. Immunohistochemical analyses in rats demonstrated that exposure to cranial irradiation with $10 \mathrm{~Gy}$ triggered activation of ADK in the hippocampus and this was associated with astrogliosis and increased expression of glial fibrillary acidic protein (GFAP). Treatment with a pharmacologic inhibitor of ADK for 6 days prior to cranial irradiation significantly improved behavioral performance of the animals at 1 month post exposure and this was associated with reduced levels of radiation-induced astrogliosis and ADK immunoreactivity in the hippocampus [238,239]. The authors concluded that extracellular adenosine exerts neuroprotection against radiation-induced pathology and other neurological comorbidities [239,261]. Despite the important role of adenosine in the regulation of brain homeostasis and radioprotection so far, the role of CD73 in acute and chronic brain injury has not yet been investigated in detail. In studies about multiple sclerosis it was shown that postmortem samples of the brain from multiple sclerosis patients expressed high levels of CD73 in the microvasculature; moreover enhanced levels of soluble serum CD73 activity and skin microvascular CD73 expression were observed after treatment with IFN- $\beta$ [262,263]. It is suggested that CD73 upregulation and subsequent adenosine production might contribute to the protective effects of IFN- $\beta$ therapy in multiple sclerosis patient through improvement of the endothelial barrier function [262].

\section{Conclusions}

RT-induced direct or indirect cell death of resident cells, the resulting systemic responses to the local damage, e.g., tissue inflammation, hypoxia, vascular remodeling, and the accumulation of immune cells with disease-promoting phenotypes, contribute to the adverse late effects of RT, particularly chronic progressive pathologies such as tissue fibrosis. As outlined above, adenosinergic signaling orchestrates inflammation and repair processes in various tissues to maintain or reconstitute tissue homeostasis. However, CD73 and adenosine play dual roles in acute damage models, and chronic progressive pathologies. The role of adenosinergic signaling in fibrotic disease has been studied in preclinical models in various tissues using ADA-deficient mice or treatment with bleomycin or exposure to ionizing radiation, respectively. These investigations revealed that chronic activation of CD73/adenosine signaling mostly plays a pathologic role in fibrotic disease, as demonstrated in the lung, the skin and liver $[74,75,141,143,243,264]$. This assumption is corroborated by reports from ADA-deficient patients: These studies demonstrate that ADA-deficient patients develop renal complications (sclerosis) as well as pulmonary complications (pneumonitis, pulmonary alveolar proteinosis, fibrosis) [265-267]. Moreover, adenosine levels are also increased in patients with chronic obstructive pulmonary disease [268]. Despite the protective role of the high affinity adenosine receptor ADORA2A in acute disease models [253,260] ADORA2A also contributed to the pathologic actions of high adenosine concentrations in dermal fibrosis $[75,230,246,247]$. Instead, ADORA2B has been identified as a major pathologic driver in models of chronic lung disease [143,226-228].

Figure 2 summarizes our current view on the role of adenosinergic signaling in acute and chronic adverse late effects in the lung, the skin, the kidney, the CNS and the gut presented in this review that are induced either by exposure to ionizing radiation, bleomycin or genetically-induced high adenosine levels. 


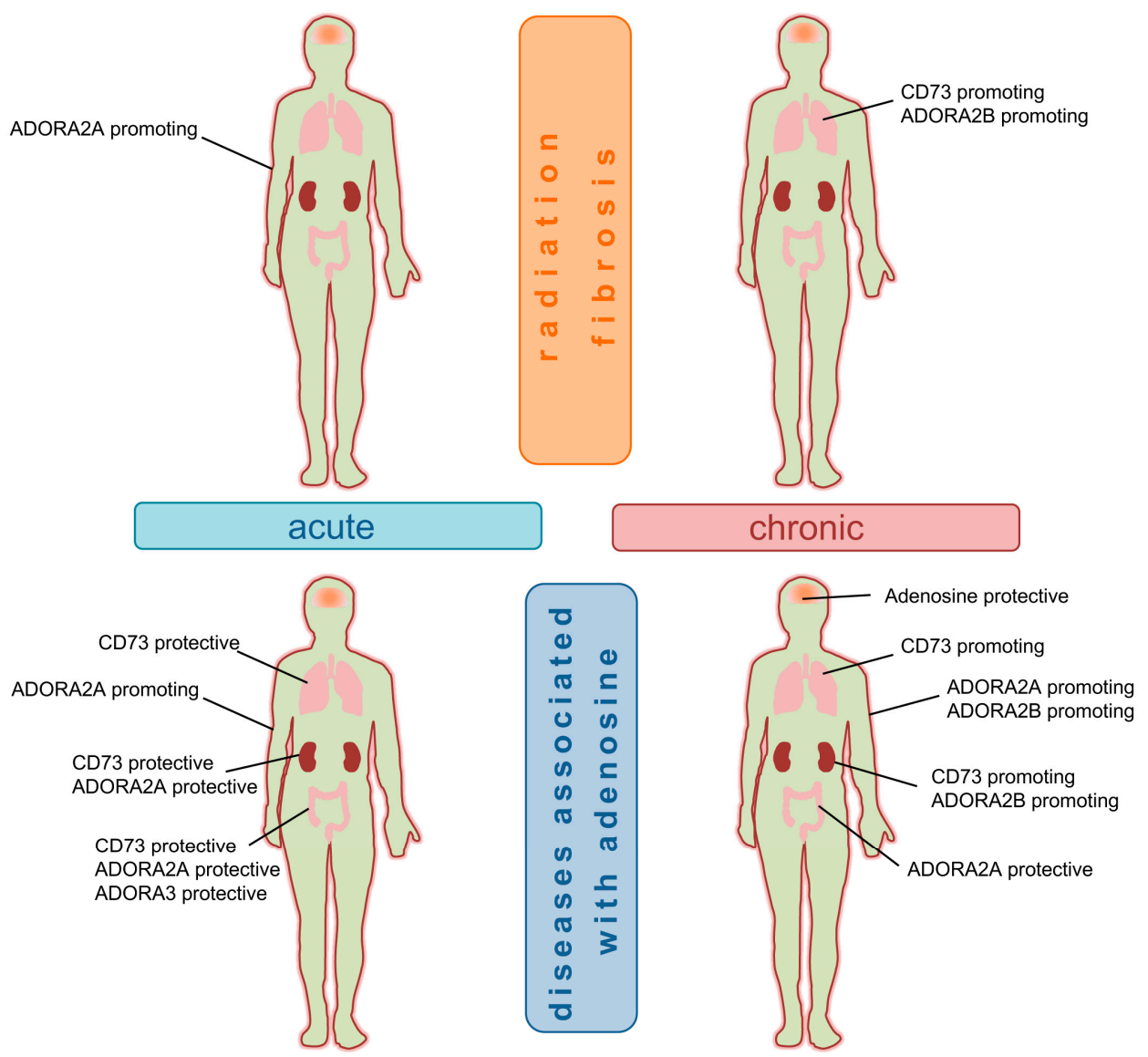

Figure 2. Role of Purinergic Signaling in acute and chronic disease states. Schematic overview about the different roles of components of the purinergic signaling system in acute versus chronic as well as radiation-induced versus adenosine-induced. The role of the different components is highly tissueand model-dependent so that no general conclusions can be drawn, although there is a tendency for CD73 being a protector in acute injury models and a disease promotor in chronic injury models as well as for ADORA2B having pathologic functions in chronic disease models. (The human silhouette is only representative for a corpus. Results are obtained from clinical and preclinical data).

In our hands, the pathogenic role of CD73/adenosine signaling in radiation-induced pulmonary fibrosis could be attributed amongst others to their ability to promote accumulation of alternatively activated pathologic macrophages in the irradiated lung tissue [243]. Interfering with signals driving the recruitment and/or alternative activation of macrophages in mice lacking CCR2 or by treatment with mAB against CSF-1R or CTGF attenuated radiation-induced lung fibrosis in mice $[69,180,269,270]$, corroborating the pathologic role of alternatively activated macrophages in the development and progression of RILF or radiation-induced renal fibrosis, respectively $[270,271]$. The accumulation of macrophages expressing markers of alternative activation seems to be a common feature of several fibrotic diseases, e.g., IR-induced pulmonary fibrosis, bleomycin-induced pulmonary and dermal fibrosis, and idiopathic pulmonary fibrosis [96,226,243,248,270,272-274]. However their role in the disease pathogenesis remains controversial: While macrophages expressing M2-like markers could be linked to disease outcome in radiation-induced renal and lung fibrosis [243,270,271], a contribution of macrophages $[275,276]$ or the accumulation of $\mathrm{T}$ cells and no role for macrophages [75] had been observed in radiation-induced dermal fibrosis. Herein it is highly likely that on myeloid cells ADORA2B may be a major pathologic driver [226].

Influx of $\mathrm{T}$ cells is another common phenomenon in irradiated tissues including the lung and the skin $[68,75,157,277]$ (for a review see [278]). Adenosine signaling via ADORA2A on $\mathrm{T}_{\text {reg }}$ promoted $\mathrm{T}_{\text {reg }}$ 
development and their immunosuppressive function [279]; this suggests that the elevated levels of $\mathrm{T}_{\text {reg }}$ observed during the pneumonitic and fibrotic phase might be due to high extracellular adenosine concentrations $[74,280]$. $T_{\text {regs }}$ are induced by TGF- $\beta$ [281] and this cytokine is found early after lung injury as well as during the fibrotic phase so that their appearance could well be related to the induction of this pro-fibrotic mediator [282-284]. Vice-versa, $\mathrm{T}_{\text {reg }}$ secrete TGF- $\beta$, a mechanism by which they could drive fibrotic actions of other cells $[285,286]$. Moreover TGF- $\beta$ modulates CD73/adenosine signaling directly: TGF- $\beta$ induced CD73 expression on murine $\mathrm{CD} 4^{+}$and $\mathrm{CD} 8^{+} \mathrm{T}$ cells even in the absence of Foxp3 leading to adenosine-generation and immunosuppression [287,288]. While the presence of $\mathrm{T}_{\text {reg }}$ aggravated BLM-induced lung fibrosis in mice [289] $\mathrm{T}_{\text {reg-depletion with an anti-CD25 }}$ antibody inhibited fibrocyte recruitment and reduced radiation-induced pulmonary fibrosis [290].

Altogether these observations highlight a functional relevance of M2-like macrophages, $\mathrm{T}_{\text {reg, }}$, or both, in fibrotic disease induced by chronic adenosine accumulation, at least in mice. Of note, a recent report highlighted a switch towards fibrosis-associated M2-like macrophage/T-helper cell type 2-like polarized phenotypes also in mice exposed to a clinically more relevant fractionated WTI [46].

The differences in the role of CD73/adenosine signaling in different pathologies presented here strongly suggest a contribution of differences in the characteristics of the tissues investigated [215]. In this context, differences in the tissue environment such as extracellular matrix composition, immune cell repertoire, expression of components of the CD73/adenosine signaling pathway on resident cells, recruited immune cells or fibroblasts (e.g., adenosine receptors), or the expression of CD73/adenosine-modulating signaling molecules may play a role as discussed in detail elsewhere [216]. Furthermore, differences in the radiosensitivity of specific resident cells or resident immune cells, or in the behavior of irradiated tissue stem cells may also play a role [243,291-294]. Finally, these differences might also be due to tissue-specific expression patterns of fibrosis-modulating signaling molecules in resident cells or recruited immune cells, tissue-specific damage responses, or both $[215,216]$.

For example, the data obtained so far suggest that ADORA2B may play a more important pathogenic role than ADORA2A in the pathogenesis of radiation-induced pulmonary fibrosis, BLM-induced pulmonary fibrosis, idiopathic pulmonary fibrosis and chronic kidney disease, whereas ADORA2A seems to be a major player in radiation- and BLM-induced dermal fibrosis. It is thus tempting to speculate that ADORs have more comparable functions in models of radiation-induced tissue fibrosis in lung, gut and kidneys, and that their functions in the regulation of the immune environment of these tissues might be distinct of those in the skin. Interestingly, new findings about disease-promoting functions of ADORA2B in dermal fibrosis [248] indicate an even more complex network between disease-promoting and protective functions of the ADORs in acute and chronic injury models, which also depend on the tissue investigated.

However, it has also to be considered that the models of radiation-induced fibrosis in the lung, gut, kidney and skin are characterized by substantial differences with respect to the radiation dose (15 Gy in the lung, 12-18 Gy in the intestine, 8-10 Gy WBI for kidney injury versus 35-40 Gy in the skin) and the time course (weeks versus months). Thus, some of the differences in the findings about the roles of ADORA2A and ADORA2B in radiation-induced dermal and pulmonary fibrosis may well be due to the differences in the damage model [42].

However, it remains to be investigated if such distinct functions are due to differences in the tissue environment, or can at least in part be attributed to the differences in the radiation dose as skin fibrosis was initiated by applying a single high dose to the organ whereas the models for the other tissues use rather intermediate radiation doses.

\section{Outlook-Clinical Translational Perspectives}

Clinical RT aims to expose the tumor volume to the maximal dose for reducing tumor burden while sparing normal tissues to minimize the risk for long-term injury. However, adverse late effects of IR in normal tissues still limit successful RT. 
To overcome this limitation radiobiologists, focus on developing innovative biological strategies that are designed to interfere selectively with the pathologic processes driving RT-induced adverse late effects without protecting the tumor and thereby can prevent, attenuate, or reverse acute and late RT-induced normal tissue toxicities. Such treatments would be suited to improve the quality of life of irradiated patients, or allow for treatment intensification efforts at least under certain conditions $[3,7]$.

As outlined in this review chronic activation of CD73/adenosine signaling mostly plays a pathogenic role in chronic radiation-induced adverse late effects and thus constitutes an attractive therapeutic target for attenuating the adverse late effects of RT. However, the therapeutic ratio can also be improved when RT is combined with chemotherapy or molecularly targeted drugs that are suited to radiosensitize the tumor cells, to overcome resistance-promoting signals in the tumor environment, or both $[5,23]$. Research in radiation biology has therefore also a strong focus on defining innovative biological concepts to specifically increase the radiosensitivity of the tumor tissue without enhancing the risk of normal tissue complications. This may also allow to reduce the RT dose without reducing treatment efficacy.

An optimal strategy for increasing the therapeutic ratio would thus sensitize the tumor to the cytotoxic effects of IR and at the same time protect normal tissues from its adverse late effects. As nicely highlighted in recent reviews, extracellular adenosine is also generated at high levels in the microenvironment of solid tumors, particularly in the context of hypoxia [126,295-298]. High extracellular adenosine levels in the tumor microenvironment play a critical role in tumor progression on the one hand by direct stimulation of tumor cell proliferation, migration, invasion, metastatic dissemination $[299,300]$ and on the other hand by potent suppression of antitumor immunity (for more details see below). Furthermore, first studies in patient samples point to a correlation between high CD73 expression and poor prognosis in cancer, e.g., in non-small cell lung cancer (NSCLC), triple negative breast cancer, high grade serous ovarian cancer, head and neck squamous cell carcinoma (HNSCC) [301-305].

In more detail, release of ATP through exocytosis or Pannexin-1 channels and subsequent CD39/CD73-dependent extracellular degradation to adenosine contribute to the accumulation of non-physiologically high levels of adenosine in the tumor microenvironment, particularly in hypoxic tumors that may reach extracellular concentrations in the $\mu \mathrm{M}$ range (0.2 to $100 \mu \mathrm{M}$ ) compared to $10-300$ $\mathrm{nM}$ in normal tissues [74,121,122,126,127]. Various preclinical studies demonstrate that expression of CD73 on tumor cells and the resulting adenosine generation and signaling directly support tumor cell proliferation and neovascularization, as well as tumor metastasis [306-310]. For example, genetic loss or pharmacologic inhibition of CD73 as well as inhibition of ADORA2B reduced the metastatic potential of tumor cells in preclinical studies [306,309,311-314]. Patient studies confirmed increased levels of CD73 in metastatic tumors [315,316]. Interestingly, high levels of CD73 have been associated with resistance to HER2/ErbB2 inhibitor therapy in preclinical breast cancer models and poor clinical outcome of breast cancer patients under Trastuzumab therapy [305]. Moreover, CD73 was induced during T-cell immunotherapy in a murine melanoma in relapsed tumors which acquired a mesenchymal-like phenotype [317]. In line with these preclinical investigations the authors of this study also detected up-regulation of CD73 in melanoma patients progressing under adoptive T-cell transfer or immune checkpoint blockade [317]. These observations point to an important role of CD73 and adenosine signaling as a mechanism of intrinsic or adaptive resistance that may be amenable to therapeutic targeting.

Importantly, CD73 and adenosine also act as modulators of tumor immunity with potent immunosuppressive actions and thereby support tumor immune escape [304,308,310,318-323]. The immunomodulatory actions of CD73 and adenosine and their contribution to tumor immune escape include for example inhibition of $\mathrm{CD}^{+}$and $\mathrm{CD} 8^{+} \mathrm{T}$ cells, natural killer cells and antigen-presenting dendritic cells as well as the induction of immunosuppressive cells such as $\mathrm{T}_{\text {reg, }}$, myeloid-derived suppressor cells (MDSCs), and macrophages with alternative M2 like activation state that have been extensively summarized elsewhere [103,323-326] and will therefore not be discussed in more 
detail here. Pharmacologic inhibition of CD73, ADORA2A, or both, relieved adenosine-mediated immunosuppression, improved antitumor immune responses and treatment outcome when given alone or in combination with other immunotherapies in preclinical investigations [325,327-331]. Of note, inhibition of CD73 by a clinically relevant inhibitory antibody (MEDI9447) significantly altered both, myeloid and lymphoid cells in the microenvironment of syngeneic murine tumors; these changes involved increases in $\mathrm{CD}^{+}$effector cells and activated macrophages and correlated with responding compared to non-responding tumors [329] which is reminiscent of our findings in the irradiated murine lung [74,243]. Importantly, CD73-inhibition not only enhanced control of local tumors but also of tumor metastases, and revealed increased efficacy in combination with anti-PD-1 antibodies [329,332].

In our hands, exposure of mice to a single high dose whole thorax irradiation lead to a time-dependent induction of CD73 expression and activity in non-hematopoietic and hematopoietic host cells. Furthermore, chronic activation of CD73 and accumulation of adenosine were critical to the phenotypic switch of infiltrating innate and adaptive immune cells towards immunosuppressive cell types [74,243]. It is thus highly likely that RT-induced damage might also trigger release of adenosine, activation of CD73, or both, in the irradiated tumor microenvironment; hypoxia-induced or RT-induced increase in extracellular adenosine levels might then limit RT-induced immune enhancement and increase resistance to combined radioimmunotherapy by adenosine-mediated immunosuppression $[42,72,244,295,333]$. Intriguingly, circulating $\mathrm{CD} 4^{+} \mathrm{T}$ cells and $\mathrm{CD} 4{ }^{+} \mathrm{CD} 25^{\mathrm{hi}}$ $\mathrm{T}_{\text {reg }}$ of HNSCC patients including patients that had received RT as part of multimodal treatment displayed up-regulated expression of CD39 and hydrolyzed ATP at higher rates and produced higher

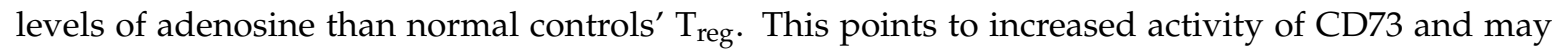
further dampen anti-tumor immune responses in irradiated patients [104]. Nevertheless the role of CD73/adenosine signaling in human $\mathrm{T}_{\text {reg }}$ needs to be further elucidated since $\mathrm{T}_{\text {reg }}$ show mainly enriched intracellular CD73 expression but remain negative for CD73 surface expression. Thus, human $\mathrm{T}_{\text {reg }}$ need to cooperate with another subset of cells, expressing surface-bound CD73, to favor adenosine-mediated immune suppression, and this could largely impact the use of new therapeutic drugs targeting the CD73/adenosine pathway.

We thus propose that the $\mathrm{CD} 73 /$ adenosine signaling is an attractive therapeutic target for improving the therapeutic gain of RT: we expect that pharmacologic inhibition of CD73/adenosine signaling will not only protect irradiated tissues from early and late adverse side effects of irradiation but block at the same time tumor-promoting effects of CD73/adenosine signaling in the tumor environment and overcome CD73/adenosine-mediated tumor immune escape [42,244]. As mentioned before the expression pattern of CD39 and CD73 on immune cells $\left(\mathrm{T}_{\text {reg, }} \mathrm{CD} 4^{+} \mathrm{T}\right.$ cells, CD8 ${ }^{+} \mathrm{T}$ cells, $\mathrm{B}$ cells and macrophages) differs between mice and humans. These differences might impact the role of CD73/adenosine signaling in irradiated normal and tumor tissues and impede translation into the clinical situation. Thus, further work is required to validate the role of the CD73/adenosine pathway in patient samples, particularly with respect to normal tissues. That the CD73/adenosine pathway might be clinical relevant in normal tissue toxicities comes from existing data of COPD and IPF patients demonstrating that the CD73/adenosine pathway and A2BR signaling promotes inflammation and profibrotic mediators in the lung [96]. Moreover, the efficacy of targeting CD73/adenosine signaling in human pathologies needs to be (further) elucidated.

Several therapeutic options exist to target adverse CD73/adenosine signaling: (i) avoid excess extracellular adenosine accumulation by inhibitory CD73 antibodies [74,313,322]; (ii) degrade excess adenosine by application of PEG-ADA [74] which is already successfully used since years in the treatment of ADA deficiency in patients [334]; (iii) impair pathologic actions of adenosine by inhibitors of disease-promoting ADORs [138], respectively. The hypoxia-induced, hypoxia-inducible factor- 1 alpha (HIF-1 $\alpha$ )-dependent expression of CD73 and ADORAs in tumor cells and host cells [219,320,335-337] make CD73 and adenosine promising targets particularly for tumors with pronounced hypoxia, high HIF-1 $\alpha$-expression, or both, (e.g., [244,295]). 


\section{Final Remarks}

The biology-based optimization of RT requires the identification of biological factors that are linked to the radiosensitivity of normal tissues or tumor tissues and that are amenable to therapeutic targeting. To our view, the adenosinergic signaling pathway offers multiple possibilities to improve RT outcome: (i) protecting the normal tissue from adverse late effects like tissue fibrosis, (ii) sensitizing the tumor tissue for radiotherapy by relieving intrinsic or hypoxia-driven adenosinergic immune suppression, and (iii) improving tumor control by reducing angiogenesis and metastatic potential. Successful translation of such approaches into the clinic will largely depend on the definition of reliable biomarkers that predict individual radiosensitivity in patients. In the era of "multi-omics" research focusses on the systematic analysis of individual gene, miRNA or protein expression profiles in irradiated tumor and normal tissues of individual patients in order to define expression signatures predictive for the radiosensitivity of tumor and normal tissues [5]. Genomic interrogation for biomarkers of tumor radiosensitivity and normal tissue toxicity such as the CD73/adenosine pathway might well be suited to gain new mechanistic insight into tissue-specific roles of specific immune cell types from the innate and adaptive immune system, and disease-promoting aspects of the multifaceted cross-talk between damaged resident cells, extracellular matrix molecules, soluble mediators and infiltrating immune cells including tissue-specific activation of signaling pathways in the irradiated tissue environment. The identification of such predictive profiles will facilitate the selection of the individual RT dose and of appropriate combination strategies for improving the therapeutic ratio in the future by targeting immunomodulatory pathways such as the CD73/adenosine pathway.

Author Contributions: S.d.L., F.W. and V.J. contributed equally to the writing of this review article.

Funding: The work was supported by grants of the Deutsche Forschungsgemeinschaft (DFG) grant numbers GRK1739/2 and JE275/4-1 (VJ), and the Bundesministerium für Bildung und Forschung (BMBF) grant number 02NUK47D (VJ).

Acknowledgments: We acknowledge support by the Open Access Publication Fund of the University of Duisburg-Essen.

Conflicts of Interest: The authors declare that the research was conducted in the absence of any commercial or financial relationships that could be construed as a potential conflict of interest.

\section{References}

1. National_Cancer_Institute. Available online: https://www.cancer.gov/about-cancer/understanding/statistics (accessed on 11 October 2019).

2. World Health Organization. Latest Global Cancer Data. Available online: https://www.who.int/cancer/ PRGlobocanFinal.pdf (accessed on 11 October 2019).

3. Begg, A.C.; Stewart, F.A.; Vens, C. Strategies to improve radiotherapy with targeted drugs. Nat. Rev. Cancer 2011, 11, 239-253. [CrossRef]

4. Yarbro, C.H.; Wujcik, D.; Gobel, B.H. Cancer Nursing: Principles and Practice, 7th ed.; Jones and Bartlett Publishers: Sudbury, MA, USA, 2011; pp. xlii, 1940, 1942 of plates.

5. Bristow, R.G.; Alexander, B.; Baumann, M.; Bratman, S.V.; Brown, J.M.; Camphausen, K.; Choyke, P.; Citrin, D.; Contessa, J.N.; Dicker, A.; et al. Combining precision radiotherapy with molecular targeting and immunomodulatory agents: A guideline by the American Society for Radiation Oncology. Lancet Oncol. 2018, 19, e240-e251. [CrossRef]

6. Kong, F.M.; Ten Haken, R.; Eisbruch, A.; Lawrence, T.S. Non-small cell lung cancer therapy-related pulmonary toxicity: An update on radiation pneumonitis and fibrosis. Semin. Oncol. 2005, 32, S42-S54. [CrossRef]

7. De Ruysscher, D.; Niedermann, G.; Burnet, N.G.; Siva, S.; Lee, A.W.M.; Hegi-Johnson, F. Radiotherapy toxicity. Nat. Rev. Dis. Primers 2019, 5, 13. [CrossRef]

8. Herman, J.M.; Narang, A.K.; Griffith, K.A.; Zalupski, M.M.; Reese, J.B.; Gearhart, S.L.; Azad, N.S.; Chan, J.; Olsen, L.; Efron, J.E.; et al. The quality-of-life effects of neoadjuvant chemoradiation in locally advanced rectal cancer. Int. J. Radiat. Oncol. Biol. Phys. 2013, 85, e15-e19. [CrossRef] 
9. Budach, W.; Hehr, T.; Budach, V.; Belka, C.; Dietz, K. A meta-analysis of hyperfractionated and accelerated radiotherapy and combined chemotherapy and radiotherapy regimens in unresected locally advanced squamous cell carcinoma of the head and neck. BMC Cancer 2006, 6, 28. [CrossRef]

10. Morgan, M.A.; Parsels, L.A.; Maybaum, J.; Lawrence, T.S. Improving the efficacy of chemoradiation with targeted agents. Cancer Discov. 2014, 4, 280-291. [CrossRef]

11. Orth, M.; Lauber, K.; Niyazi, M.; Friedl, A.A.; Li, M.; Maihofer, C.; Schuttrumpf, L.; Ernst, A.; Niemoller, O.M.; Belka, C. Current concepts in clinical radiation oncology. Radiat. Environ. Biophys. 2014, 53, 1-29. [CrossRef]

12. Plastaras, J.P.; Berman, A.T.; Freedman, G.M. Special cases for proton beam radiotherapy: Re-irradiation, lymphoma, and breast cancer. Semin. Oncol. 2014, 41, 807-819. [CrossRef]

13. Steinmeier, T.; Schulze Schleithoff, S.; Timmermann, B. Evolving Radiotherapy Techniques in Paediatric Oncology. Clin. Oncol. 2019, 31, 142-150. [CrossRef]

14. Favaudon, V.; Caplier, L.; Monceau, V.; Pouzoulet, F.; Sayarath, M.; Fouillade, C.; Poupon, M.F.; Brito, I.; Hupe, P.; Bourhis, J.; et al. Ultrahigh dose-rate FLASH irradiation increases the differential response between normal and tumor tissue in mice. Sci. Transl. Med. 2014, 6, 245ra293. [CrossRef] [PubMed]

15. Vozenin, M.C.; De Fornel, P.; Petersson, K.; Favaudon, V.; Jaccard, M.; Germond, J.F.; Petit, B.; Burki, M.; Ferrand, G.; Patin, D.; et al. The Advantage of FLASH Radiotherapy Confirmed in Mini-pig and Cat-cancer Patients. Clin. Cancer Res. 2019, 25, 35-42. [CrossRef] [PubMed]

16. Montay-Gruel, P.; Petersson, K.; Jaccard, M.; Boivin, G.; Germond, J.F.; Petit, B.; Doenlen, R.; Favaudon, V.; Bochud, F.; Bailat, C.; et al. Irradiation in a flash: Unique sparing of memory in mice after whole brain irradiation with dose rates above 100Gy/s. Radiother. Oncol. 2017, 124, 365-369. [CrossRef] [PubMed]

17. Schuler, E.; Trovati, S.; King, G.; Lartey, F.; Rafat, M.; Villegas, M.; Praxel, A.J.; Loo, B.W., Jr.; Maxim, P.G. Experimental Platform for Ultra-high Dose Rate FLASH Irradiation of Small Animals Using a Clinical Linear Accelerator. Int. J. Radiat. Oncol. Biol. Phys. 2017, 97, 195-203. [CrossRef] [PubMed]

18. Bourhis, J.; Sozzi, W.J.; Jorge, P.G.; Gaide, O.; Bailat, C.; Duclos, F.; Patin, D.; Ozsahin, M.; Bochud, F.; Germond, J.F.; et al. Treatment of a first patient with FLASH-radiotherapy. Radiother. Oncol. 2019, 139, 18-22. [CrossRef]

19. Bourhis, J.; Montay-Gruel, P.; Goncalves Jorge, P.; Bailat, C.; Petit, B.; Ollivier, J.; Jeanneret-Sozzi, W.; Ozsahin, M.; Bochud, F.; Moeckli, R.; et al. Clinical translation of FLASH radiotherapy: Why and how? Radiother. Oncol. 2019, 139, 11-17. [CrossRef]

20. Harrington, K.J. Ultrahigh Dose-rate Radiotherapy: Next Steps for FLASH-RT. Clin. Cancer Res. 2019, 25, 3-5. [CrossRef]

21. Moeller, B.J.; Dewhirst, M.W. HIF-1 and tumour radiosensitivity. Br. J. Cancer 2006, 95, 1-5. [CrossRef]

22. Holzel, M.; Bovier, A.; Tuting, T. Plasticity of tumour and immune cells: A source of heterogeneity and a cause for therapy resistance? Nat. Rev. Cancer 2013, 13, 365-376. [CrossRef]

23. Kirsch, D.G.; Diehn, M.; Kesarwala, A.H.; Maity, A.; Morgan, M.A.; Schwarz, J.K.; Bristow, R.; Demaria, S.; Eke, I.; Griffin, R.J.; et al. The Future of Radiobiology. J. Natl. Cancer Inst. 2018, 110, 329-340. [CrossRef]

24. Menon, S.S.; Uppal, M.; Randhawa, S.; Cheema, M.S.; Aghdam, N.; Usala, R.L.; Ghosh, S.P.; Cheema, A.K.; Dritschilo, A. Radiation Metabolomics: Current Status and Future Directions. Front. Oncol. 2016, 6, 20. [CrossRef] [PubMed]

25. Wouters, B.G.; Koritzinsky, M. Hypoxia signalling through mTOR and the unfolded protein response in cancer. Nat. Rev. Cancer 2008, 8, 851-864. [CrossRef] [PubMed]

26. Matschke, J.; Wiebeck, E.; Hurst, S.; Rudner, J.; Jendrossek, V. Role of SGK1 for fatty acid uptake, cell survival and radioresistance of NCI-H460 lung cancer cells exposed to acute or chronic cycling severe hypoxia. Radiat. Oncol. 2016, 11, 75. [CrossRef] [PubMed]

27. Hlouschek, J.; Hansel, C.; Jendrossek, V.; Matschke, J. The Mitochondrial Citrate Carrier (SLC25A1) Sustains Redox Homeostasis and Mitochondrial Metabolism Supporting Radioresistance of Cancer Cells With Tolerance to Cycling Severe Hypoxia. Front. Oncol. 2018, 8, 170. [CrossRef] [PubMed]

28. Baumann, M.; Krause, M.; Hill, R. Exploring the role of cancer stem cells in radioresistance. Nat. Rev. Cancer 2008, 8, 545-554. [CrossRef] [PubMed]

29. Evers, P.; Lee, P.P.; DeMarco, J.; Agazaryan, N.; Sayre, J.W.; Selch, M.; Pajonk, F. Irradiation of the potential cancer stem cell niches in the adult brain improves progression-free survival of patients with malignant glioma. BMC Cancer 2010, 10, 384. [CrossRef] 
30. Scott, J.G.; Berglund, A.; Schell, M.J.; Mihaylov, I.; Fulp, W.J.; Yue, B.; Welsh, E.; Caudell, J.J.; Ahmed, K.; Strom, T.S.; et al. A genome-based model for adjusting radiotherapy dose (GARD): A retrospective, cohort-based study. Lancet Oncol. 2017, 18, 202-211. [CrossRef]

31. Ganss, R.; Ryschich, E.; Klar, E.; Arnold, B.; Hammerling, G.J. Combination of T-cell therapy and trigger of inflammation induces remodeling of the vasculature and tumor eradication. Cancer Res. 2002, 62, 1462-1470.

32. Martinez-Zubiaurre, I.; Chalmers, A.J.; Hellevik, T. Radiation-Induced Transformation of Immunoregulatory Networks in the Tumor Stroma. Front. Immunol. 2018, 9, 1679. [CrossRef]

33. Spigel, D.R.; Hainsworth, J.D.; Yardley, D.A.; Raefsky, E.; Patton, J.; Peacock, N.; Farley, C.; Burris, H.A., 3rd; Greco, F.A. Tracheoesophageal fistula formation in patients with lung cancer treated with chemoradiation and bevacizumab. J. Clin. Oncol. 2010, 28, 43-48. [CrossRef]

34. Niyazi, M.; Maihoefer, C.; Krause, M.; Rodel, C.; Budach, W.; Belka, C. Radiotherapy and "new" drugs-new side effects? Radiat. Oncol. 2011, 6, 177. [CrossRef] [PubMed]

35. Mangoni, M.; Vozenin, M.C.; Biti, G.; Deutsch, E. Normal tissues toxicities triggered by combined anti-angiogenic and radiation therapies: Hurdles might be ahead. Br. J. Cancer 2012, 107, 308-314. [CrossRef] [PubMed]

36. Shibaki, R.; Akamatsu, H.; Fujimoto, M.; Koh, Y.; Yamamoto, N. Nivolumab induced radiation recall pneumonitis after two years of radiotherapy. Ann. Oncol. 2017, 28, 1404-1405. [CrossRef] [PubMed]

37. Montay-Gruel, P.; Meziani, L.; Yakkala, C.; Vozenin, M.C. Expanding the therapeutic index of radiation therapy by normal tissue protection. Br. J. Radiol. 2018, 92, 20180008. [CrossRef] [PubMed]

38. Jackson, S.P.; Bartek, J. The DNA-damage response in human biology and disease. Nature 2009, 461, 1071-1078. [CrossRef]

39. Lord, C.J.; Ashworth, A. The DNA damage response and cancer therapy. Nature 2012, 481, 287-294. [CrossRef]

40. Morgan, M.A.; Lawrence, T.S. Molecular Pathways: Overcoming Radiation Resistance by Targeting DNA Damage Response Pathways. Clin. Cancer Res. 2015, 21, 2898-2904. [CrossRef]

41. Kelsey, C.R.; Horwitz, M.E.; Chino, J.P.; Craciunescu, O.; Steffey, B.; Folz, R.J.; Chao, N.J.; Rizzieri, D.A.; Marks, L.B. Severe pulmonary toxicity after myeloablative conditioning using total body irradiation: An assessment of risk factors. Int. J. Radiat. Oncol. Biol. Phys. 2011, 81, 812-818. [CrossRef]

42. Wirsdorfer, F.; Jendrossek, V. Modeling DNA damage-induced pneumopathy in mice: Insight from danger signaling cascades. Radiat. Oncol. 2017, 12, 142. [CrossRef]

43. Chargari, C.; Riet, F.; Mazevet, M.; Morel, E.; Lepechoux, C.; Deutsch, E. Complications of thoracic radiotherapy. Presse Med. 2013, 42, e342-e351. [CrossRef]

44. Bentzen, S.M. Preventing or reducing late side effects of radiation therapy: Radiobiology meets molecular pathology. Nat. Rev. Cancer 2006, 6, 702-713. [CrossRef] [PubMed]

45. Graves, P.R.; Siddiqui, F.; Anscher, M.S.; Movsas, B. Radiation pulmonary toxicity: From mechanisms to management. Semin. Radiat. Oncol. 2010, 20, 201-207. [CrossRef] [PubMed]

46. Zhou, C.; Moustafa, M.R.; Cao, L.; Kriegsmann, M.; Winter, M.; Schwager, C.; Jones, B.; Wang, S.; Bauerle, T.; Zhou, P.K.; et al. Modeling and multiscale characterization of the quantitative imaging based fibrosis index reveals pathophysiological, transcriptome and proteomic correlates of lung fibrosis induced by fractionated irradiation. Int. J. Cancer 2019, 144, 3160-3173. [CrossRef] [PubMed]

47. Arpin, D.; Perol, D.; Blay, J.Y.; Falchero, L.; Claude, L.; Vuillermoz-Blas, S.; Martel-Lafay, I.; Ginestet, C.; Alberti, L.; Nosov, D.; et al. Early variations of circulating interleukin-6 and interleukin-10 levels during thoracic radiotherapy are predictive for radiation pneumonitis. J. Clin. Oncol. 2005, 23, 8748-8756. [CrossRef] [PubMed]

48. Rubin, P.; Johnston, C.J.; Williams, J.P.; McDonald, S.; Finkelstein, J.N. A perpetual cascade of cytokines postirradiation leads to pulmonary fibrosis. Int. J. Radiat. Oncol. Biol. Phys. 1995, 33, 99-109. [CrossRef]

49. Johnston, C.J.; Wright, T.W.; Rubin, P.; Finkelstein, J.N. Alterations in the expression of chemokine mRNA levels in fibrosis-resistant and -sensitive mice after thoracic irradiation. Exp. Lung Res. 1998, 24, 321-337. [CrossRef] [PubMed]

50. Hong, Z.Y.; Song, K.H.; Yoon, J.H.; Cho, J.; Story, M.D. An experimental model-based exploration of cytokines in ablative radiation-induced lung injury in vivo and in vitro. Lung 2015, 193, 409-419. [CrossRef]

51. Cappuccini, F.; Eldh, T.; Bruder, D.; Gereke, M.; Jastrow, H.; Schulze-Osthoff, K.; Fischer, U.; Kohler, D.; Stuschke, M.; Jendrossek, V. New insights into the molecular pathology of radiation-induced pneumopathy. Radiother. Oncol. 2011, 101, 86-92. [CrossRef] 
52. Chiang, C.S.; Liu, W.C.; Jung, S.M.; Chen, F.H.; Wu, C.R.; McBride, W.H.; Lee, C.C.; Hong, J.H. Compartmental responses after thoracic irradiation of mice: Strain differences. Int. J. Radiat. Oncol. Biol. Phys. 2005, 62, 862-871. [CrossRef]

53. Eldh, T.; Heinzelmann, F.; Velalakan, A.; Budach, W.; Belka, C.; Jendrossek, V. Radiation-induced changes in breathing frequency and lung histology of C57BL/6J mice are time- and dose-dependent. Strahlentherapie und Onkologie 2012, 188, 274-281. [CrossRef]

54. Johnston, C.J.; Williams, J.P.; Elder, A.; Hernady, E.; Finkelstein, J.N. Inflammatory cell recruitment following thoracic irradiation. Exp. Lung Res. 2004, 30, 369-382. [CrossRef] [PubMed]

55. Johnston, C.J.; Williams, J.P.; Okunieff, P.; Finkelstein, J.N. Radiation-induced pulmonary fibrosis: Examination of chemokine and chemokine receptor families. Radiat. Res. 2002, 157, 256-265. [CrossRef]

56. Abdollahi, A.; Li, M.; Ping, G.; Plathow, C.; Domhan, S.; Kiessling, F.; Lee, L.B.; McMahon, G.; Grone, H.J.; Lipson, K.E.; et al. Inhibition of platelet-derived growth factor signaling attenuates pulmonary fibrosis. J. Exp. Med. 2005, 201, 925-935. [CrossRef] [PubMed]

57. Heinzelmann, F.; Jendrossek, V.; Lauber, K.; Nowak, K.; Eldh, T.; Boras, R.; Handrick, R.; Henkel, M.; Martin, C.; Uhlig, S.; et al. Irradiation-induced pneumonitis mediated by the CD95/CD95-ligand system. J. Natl. Cancer Inst. 2006, 98, 1248-1251. [CrossRef]

58. Hall, E.J.; Giaccia, A.J. Radiobiology for the Radiologist, 6th ed.; Lippincott Williams \& Wilkins: Philadelphia, PA, USA, 2006; 546p.

59. Formenti, S.C.; Demaria, S. Systemic effects of local radiotherapy. Lancet Oncol. 2009, 10, 718-726. [CrossRef]

60. Herrera, F.G.; Bourhis, J.; Coukos, G. Radiotherapy combination opportunities leveraging immunity for the next oncology practice. CA Cancer J. Clin. 2017, 67, 65-85. [CrossRef]

61. Gupta, A.; Probst, H.C.; Vuong, V.; Landshammer, A.; Muth, S.; Yagita, H.; Schwendener, R.; Pruschy, M.; Knuth, A.; van den Broek, M. Radiotherapy promotes tumor-specific effector $\mathrm{CD}^{+} \mathrm{T}$ cells via dendritic cell activation. J. Immunol. 2012, 189, 558-566. [CrossRef]

62. Liang, H.; Deng, L.; Chmura, S.; Burnette, B.; Liadis, N.; Darga, T.; Beckett, M.A.; Lingen, M.W.; Witt, M.; Weichselbaum, R.R.; et al. Radiation-induced equilibrium is a balance between tumor cell proliferation and T cell-mediated killing. J. Immunol. 2013, 190, 5874-5881. [CrossRef]

63. Van Limbergen, E.J.; De Ruysscher, D.K.; Olivo Pimentel, V.; Marcus, D.; Berbee, M.; Hoeben, A.; Rekers, N.; Theys, J.; Yaromina, A.; Dubois, L.J.; et al. Combining radiotherapy with immunotherapy: The past, the present and the future. Br. J. Radiol. 2017, 90, 20170157. [CrossRef]

64. Deloch, L.; Derer, A.; Hartmann, J.; Frey, B.; Fietkau, R.; Gaipl, U.S. Modern Radiotherapy Concepts and the Impact of Radiation on Immune Activation. Front. Oncol. 2016, 6, 141. [CrossRef]

65. Dar, T.B.; Henson, R.M.; Shiao, S.L. Targeting Innate Immunity to Enhance the Efficacy of Radiation Therapy. Front. Immunol. 2018, 9, 3077. [CrossRef] [PubMed]

66. Sevenich, L. Brain-Resident Microglia and Blood-Borne Macrophages Orchestrate Central Nervous System Inflammation in Neurodegenerative Disorders and Brain Cancer. Front. Immunol. 2018, 9, 697. [CrossRef] [PubMed]

67. Ahn, G.O.; Tseng, D.; Liao, C.H.; Dorie, M.J.; Czechowicz, A.; Brown, J.M. Inhibition of Mac-1 (CD11b/CD18) enhances tumor response to radiation by reducing myeloid cell recruitment. Proc. Natl. Acad. Sci. USA 2010, 107, 8363-8368. [CrossRef] [PubMed]

68. Wirsdorfer, F.; Cappuccini, F.; Niazman, M.; de Leve, S.; Westendorf, A.M.; Ludemann, L.; Stuschke, M.; Jendrossek, V. Thorax irradiation triggers a local and systemic accumulation of immunosuppressive CD4 ${ }^{+}$ FoxP3 ${ }^{+}$regulatory T cells. Radiat. Oncol. 2014, 9, 98. [CrossRef] [PubMed]

69. Wiesemann, A.; Ketteler, J.; Slama, A.; Wirsdorfer, F.; Hager, T.; Rock, K.; Engel, D.R.; Fischer, J.W.; Aigner, C.; Jendrossek, V.; et al. Inhibition of Radiation-Induced Ccl2 Signaling Protects Lungs from Vascular Dysfunction and Endothelial Cell Loss. Antioxid. Redox Signal. 2019, 30, 213-231. [CrossRef]

70. Gajewski, T.F. The Next Hurdle in Cancer Immunotherapy: Overcoming the Non-T-Cell-Inflamed Tumor Microenvironment. Semin. Oncol. 2015, 42, 663-671. [CrossRef]

71. Pitt, J.M.; Vetizou, M.; Daillere, R.; Roberti, M.P.; Yamazaki, T.; Routy, B.; Lepage, P.; Boneca, I.G.; Chamaillard, M.; Kroemer, G.; et al. Resistance Mechanisms to Immune-Checkpoint Blockade in Cancer: Tumor-Intrinsic and -Extrinsic Factors. Immunity 2016, 44, 1255-1269. [CrossRef] 
72. Wennerberg, E.; Lhuillier, C.; Vanpouille-Box, C.; Pilones, K.A.; Garcia-Martinez, E.; Rudqvist, N.P.; Formenti, S.C.; Demaria, S. Barriers to Radiation-Induced In Situ Tumor Vaccination. Front. Immunol. 2017, 8, 229. [CrossRef]

73. Wirsdorfer, F.; de Leve, S.; Jendrossek, V. Combining Radiotherapy and Immunotherapy in Lung Cancer: Can We Expect Limitations Due to Altered Normal Tissue Toxicity? Int. J. Mol. Sci. 2018, 20. [CrossRef]

74. Wirsdorfer, F.; de Leve, S.; Cappuccini, F.; Eldh, T.; Meyer, A.V.; Gau, E.; Thompson, L.F.; Chen, N.Y.; Karmouty-Quintana, H.; Fischer, U.; et al. Extracellular Adenosine Production by ecto-5'-Nucleotidase (CD73) Enhances Radiation-Induced Lung Fibrosis. Cancer Res. 2016, 76, 3045-3056. [CrossRef]

75. Perez-Aso, M.; Mediero, A.; Low, Y.C.; Levine, J.; Cronstein, B.N. Adenosine A2A receptor plays an important role in radiation-induced dermal injury. FASEB J. 2016, 30, 457-465. [CrossRef] [PubMed]

76. Ferrari, D.; Gambari, R.; Idzko, M.; Muller, T.; Albanesi, C.; Pastore, S.; La Manna, G.; Robson, S.C.; Cronstein, B. Purinergic signaling in scarring. FASEB J. 2016, 30, 3-12. [CrossRef] [PubMed]

77. Vaughn, B.P.; Robson, S.C.; Longhi, M.S. Purinergic signaling in liver disease. Dig. Dis. 2014, 32, 516-524. [CrossRef] [PubMed]

78. Chan, E.S.; Cronstein, B.N. Adenosine in fibrosis. Mod. Rheumatol. 2010, 20, 114-122. [CrossRef]

79. Francois, V.; Shehade, H.; Acolty, V.; Preyat, N.; Delree, P.; Moser, M.; Oldenhove, G. Intestinal immunopathology is associated with decreased CD73-generated adenosine during lethal infection. Mucosal Immunol. 2015, 8, 773-784. [CrossRef]

80. Della Latta, V.; Cabiati, M.; Rocchiccioli, S.; Del Ry, S.; Morales, M.A. The role of the adenosinergic system in lung fibrosis. Pharm. Res. 2013, 76, 182-189. [CrossRef]

81. Colgan, S.P.; Eltzschig, H.K.; Eckle, T.; Thompson, L.F. Physiological roles for ecto-5' -nucleotidase (CD73). Purinergic Signal. 2006, 2, 351-360. [CrossRef]

82. Antonioli, L.; Pacher, P.; Vizi, E.S.; Hasko, G. CD39 and CD73 in immunity and inflammation. Trends Mol. Med. 2013, 19, 355-367. [CrossRef]

83. Kaufmann, A.; Musset, B.; Limberg, S.H.; Renigunta, V.; Sus, R.; Dalpke, A.H.; Heeg, K.M.; Robaye, B.; Hanley, P.J. "Host tissue damage" signal ATP promotes non-directional migration and negatively regulates toll-like receptor signaling in human monocytes. J. Biol. Chem. 2005, 280, 32459-32467. [CrossRef]

84. Yegutkin, G.G. Nucleotide- and nucleoside-converting ectoenzymes: Important modulators of purinergic signalling cascade. Biochim. Biophys. Acta 2008, 1783, 673-694. [CrossRef]

85. Piccinini, A.M.; Midwood, K.S. DAMPening inflammation by modulating TLR signalling. Mediators Inflamm. 2010, 2010. [CrossRef]

86. Adamson, S.E.; Leitinger, N. The role of pannexin1 in the induction and resolution of inflammation. FEBS Lett. 2014, 588, 1416-1422. [CrossRef]

87. Wanhainen, K.M.; Jameson, S.C.; da Silva, H.B. Self-Regulation of Memory CD8 T Cell Metabolism through Extracellular ATP Signaling. Immunometabolism 2019, 1. [CrossRef]

88. Nadel, Y.; Lecka, J.; Gilad, Y.; Ben-David, G.; Forster, D.; Reiser, G.; Kenigsberg, S.; Camden, J.; Weisman, G.A.; Senderowitz, H.; et al. Highly potent and selective ectonucleotide pyrophosphatase/phosphodiesterase I inhibitors based on an adenosine 5' -(alpha or gamma)-thio-(alpha,betaor beta,gamma)-methylenetriphosphate scaffold. J. Med. Chem. 2014, 57, 4677-4691. [CrossRef]

89. Eltzschig, H.K.; Weissmuller, T.; Mager, A.; Eckle, T. Nucleotide metabolism and cell-cell interactions. Methods Mol. Biol. 2006, 341, 73-87. [CrossRef]

90. Burnstock, G.; Boeynaems, J.M. Purinergic signalling and immune cells. Purinergic Signal. 2014, 10, $529-564$. [CrossRef]

91. Berchtold, S.; Ogilvie, A.L.; Bogdan, C.; Muhl-Zurbes, P.; Ogilvie, A.; Schuler, G.; Steinkasserer, A. Human monocyte derived dendritic cells express functional P2X and P2Y receptors as well as ecto-nucleotidases. FEBS Lett. 1999, 458, 424-428. [CrossRef]

92. Barankiewicz, J.; Dosch, H.M.; Cohen, A. Extracellular nucleotide catabolism in human B and T lymphocytes. The source of adenosine production. J. Biol. Chem. 1988, 263, 7094-7098.

93. Goepfert, C.; Imai, M.; Brouard, S.; Csizmadia, E.; Kaczmarek, E.; Robson, S.C. CD39 modulates endothelial cell activation and apoptosis. Mol. Med. 2000, 6, 591-603. [CrossRef]

94. Philippeos, C.; Telerman, S.B.; Oules, B.; Pisco, A.O.; Shaw, T.J.; Elgueta, R.; Lombardi, G.; Driskell, R.R.; Soldin, M.; Lynch, M.D.; et al. Spatial and Single-Cell Transcriptional Profiling Identifies Functionally Distinct Human Dermal Fibroblast Subpopulations. J. Invest. Dermatol. 2018, 138, 811-825. [CrossRef] 
95. Bours, M.J.; Swennen, E.L.; Di Virgilio, F.; Cronstein, B.N.; Dagnelie, P.C. Adenosine 5'-triphosphate and adenosine as endogenous signaling molecules in immunity and inflammation. Pharmacol. Ther. 2006, 112, 358-404. [CrossRef]

96. Zhou, Y.; Murthy, J.N.; Zeng, D.; Belardinelli, L.; Blackburn, M.R. Alterations in adenosine metabolism and signaling in patients with chronic obstructive pulmonary disease and idiopathic pulmonary fibrosis. PLOS ONE 2010, 5, e9224. [CrossRef]

97. Eltzschig, H.K.; Sitkovsky, M.V.; Robson, S.C. Purinergic signaling during inflammation. N. Engl. J. Med. 2012, 367, 2322-2333. [CrossRef]

98. Deaglio, S.; Dwyer, K.M.; Gao, W.; Friedman, D.; Usheva, A.; Erat, A.; Chen, J.F.; Enjyoji, K.; Linden, J.; Oukka, M.; et al. Adenosine generation catalyzed by CD39 and CD73 expressed on regulatory T cells mediates immune suppression. J. Exp. Med. 2007, 204, 1257-1265. [CrossRef]

99. Kaku, H.; Cheng, K.F.; Al-Abed, Y.; Rothstein, T.L. A novel mechanism of B cell-mediated immune suppression through CD73 expression and adenosine production. J. Immunol. 2014, 193, 5904-5913. [CrossRef]

100. Chen, X.; Shao, H.; Zhi, Y.; Xiao, Q.; Su, C.; Dong, L.; Liu, X.; Li, X.; Zhang, X. CD73 Pathway Contributes to the Immunosuppressive Ability of Mesenchymal Stem Cells in Intraocular Autoimmune Responses. Stem Cells Dev. 2016, 25, 337-346. [CrossRef]

101. Ohradanova-Repic, A.; Machacek, C.; Charvet, C.; Lager, F.; Le Roux, D.; Platzer, R.; Leksa, V.; Mitulovic, G.; Burkard, T.R.; Zlabinger, G.J.; et al. Extracellular Purine Metabolism Is the Switchboard of Immunosuppressive Macrophages and a Novel Target to Treat Diseases With Macrophage Imbalances. Front. Immunol. 2018, 9, 852. [CrossRef]

102. Breitbach, M.; Kimura, K.; Luis, T.C.; Fuegemann, C.J.; Woll, P.S.; Hesse, M.; Facchini, R.; Rieck, S.; Jobin, K.; Reinhardt, J.; et al. In Vivo Labeling by CD73 Marks Multipotent Stromal Cells and Highlights Endothelial Heterogeneity in the Bone Marrow Niche. Cell Stem Cell 2018, 22, 262-276.e7. [CrossRef]

103. Allard, B.; Longhi, M.S.; Robson, S.C.; Stagg, J. The ectonucleotidases CD39 and CD73: Novel checkpoint inhibitor targets. Immunol. Rev. 2017, 276, 121-144. [CrossRef]

104. Mandapathil, M.; Szczepanski, M.J.; Szajnik, M.; Ren, J.; Lenzner, D.E.; Jackson, E.K.; Gorelik, E.; Lang, S.; Johnson, J.T.; Whiteside, T.L. Increased ectonucleotidase expression and activity in regulatory T cells of patients with head and neck cancer. Clin. Cancer Res. 2009, 15, 6348-6357. [CrossRef]

105. Gourdin, N.; Bossennec, M.; Rodriguez, C.; Vigano, S.; Machon, C.; Jandus, C.; Bauche, D.; Faget, J.; Durand, I.; Chopin, N.; et al. Autocrine Adenosine Regulates Tumor Polyfunctional CD73 ${ }^{+} \mathrm{CD} 4^{+}$Effector T Cells Devoid of Immune Checkpoints. Cancer Res. 2018, 78, 3604-3618. [CrossRef] [PubMed]

106. Sundstrom, P.; Stenstad, H.; Langenes, V.; Ahlmanner, F.; Theander, L.; Ndah, T.G.; Fredin, K.; Borjesson, L.; Gustavsson, B.; Bastid, J.; et al. Regulatory T Cells from Colon Cancer Patients Inhibit Effector T-cell Migration through an Adenosine-Dependent Mechanism. Cancer Immunol. Res. 2016, 4, 183-193. [CrossRef] [PubMed]

107. Schuler, P.J.; Saze, Z.; Hong, C.S.; Muller, L.; Gillespie, D.G.; Cheng, D.; Harasymczuk, M.; Mandapathil, M.; Lang, S.; Jackson, E.K.; et al. Human CD4 ${ }^{+} \mathrm{CD} 39^{+}$regulatory T cells produce adenosine upon co-expression of surface CD73 or contact with $\mathrm{CD}^{+} 3^{+}$exosomes or $\mathrm{CD}^{+}{ }^{+}$cells. Clin. Exp. Immunol. 2014, 177, 531-543. [CrossRef]

108. Doherty, G.A.; Bai, A.; Hanidziar, D.; Longhi, M.S.; Lawlor, G.O.; Putheti, P.; Csizmadia, E.; Nowak, M.; Cheifetz, A.S.; Moss, A.C.; et al. CD73 is a phenotypic marker of effector memory Th17 cells in inflammatory bowel disease. Eur. J. Immunol. 2012, 42, 3062-3072. [CrossRef] [PubMed]

109. Schuler, P.J.; Macatangay, B.J.; Saze, Z.; Jackson, E.K.; Riddler, S.A.; Buchanan, W.G.; Hilldorfer, B.B.; Mellors, J.W.; Whiteside, T.L.; Rinaldo, C.R. CD4 ${ }^{+} \mathrm{CD}^{+}{ }^{+} \mathrm{T}$ cells are associated with lower T-cell activation and $\mathrm{C}$ reactive protein levels and are depleted in HIV-1 infection regardless of viral suppression. AIDS 2013, 27, 1545-1555. [CrossRef] [PubMed]

110. Bono, M.R.; Fernandez, D.; Flores-Santibanez, F.; Rosemblatt, M.; Sauma, D. CD73 and CD39 ectonucleotidases in T cell differentiation: Beyond immunosuppression. FEBS Lett. 2015, 589, 3454-3460. [CrossRef] [PubMed]

111. Schena, F.; Volpi, S.; Faliti, C.E.; Penco, F.; Santi, S.; Proietti, M.; Schenk, U.; Damonte, G.; Salis, A.; Bellotti, M.; et al. Dependence of immunoglobulin class switch recombination in B cells on vesicular release of ATP and CD73 ectonucleotidase activity. Cell Rep. 2013, 3, 1824-1831. [CrossRef] [PubMed] 
112. Zanin, R.F.; Braganhol, E.; Bergamin, L.S.; Campesato, L.F.; Filho, A.Z.; Moreira, J.C.; Morrone, F.B.; Sevigny, J.; Schetinger, M.R.; de Souza Wyse, A.T.; et al. Differential macrophage activation alters the expression profile of NTPDase and ecto-5'-nucleotidase. PLoS ONE 2012, 7, e31205. [CrossRef]

113. Eichin, D.; Laurila, J.P.; Jalkanen, S.; Salmi, M. CD73 Activity is Dispensable for the Polarization of M2 Macrophages. PLoS ONE 2015, 10, e0134721. [CrossRef]

114. Kumar, V. Adenosine as an endogenous immunoregulator in cancer pathogenesis: Where to go? Purinergic Signal. 2013, 9, 145-165. [CrossRef]

115. Hasko, G.; Csoka, B.; Nemeth, Z.H.; Vizi, E.S.; Pacher, P. A(2B) adenosine receptors in immunity and inflammation. Trends Immunol. 2009, 30, 263-270. [CrossRef] [PubMed]

116. Mikhailov, A.; Sokolovskaya, A.; Yegutkin, G.G.; Amdahl, H.; West, A.; Yagita, H.; Lahesmaa, R.; Thompson, L.F.; Jalkanen, S.; Blokhin, D.; et al. CD73 participates in cellular multiresistance program and protects against TRAIL-induced apoptosis. J. Immunol. 2008, 181, 464-475. [CrossRef] [PubMed]

117. Thompson, L.F.; Takedachi, M.; Ebisuno, Y.; Tanaka, T.; Miyasaka, M.; Mills, J.H.; Bynoe, M.S. Regulation of leukocyte migration across endothelial barriers by ECTO-5'-nucleotidase-generated adenosine. Nucleosides Nucleotides Nucleic Acids 2008, 27, 755-760. [CrossRef]

118. Thompson, L.F.; Eltzschig, H.K.; Ibla, J.C.; Van De Wiele, C.J.; Resta, R.; Morote-Garcia, J.C.; Colgan, S.P. Crucial role for ecto-5'-nucleotidase (CD73) in vascular leakage during hypoxia. J. Exp. Med. 2004, 200, 1395-1405. [CrossRef] [PubMed]

119. Davies, J.; Karmouty-Quintana, H.; Le, T.T.; Chen, N.Y.; Weng, T.; Luo, F.; Molina, J.; Moorthy, B.; Blackburn, M.R. Adenosine promotes vascular barrier function in hyperoxic lung injury. Physiol. Rep. 2014, 2. [CrossRef] [PubMed]

120. Arvilommi, A.M.; Salmi, M.; Airas, L.; Kalimo, K.; Jalkanen, S. CD73 mediates lymphocyte binding to vascular endothelium in inflamed human skin. Eur. J. Immunol. 1997, 27, 248-254. [CrossRef]

121. Hatfield, S.M.; Kjaergaard, J.; Lukashev, D.; Belikoff, B.; Schreiber, T.H.; Sethumadhavan, S.; Abbott, R.; Philbrook, P.; Thayer, M.; Shujia, D.; et al. Systemic oxygenation weakens the hypoxia and hypoxia inducible factor 1alpha-dependent and extracellular adenosine-mediated tumor protection. J. Mol. Med. 2014, 92, 1283-1292. [CrossRef]

122. Blay, J.; White, T.D.; Hoskin, D.W. The extracellular fluid of solid carcinomas contains immunosuppressive concentrations of adenosine. Cancer Res. 1997, 57, 2602-2605.

123. Fredholm, B.B. Adenosine, an endogenous distress signal, modulates tissue damage and repair. Cell Death Differ. 2007, 14, 1315-1323. [CrossRef]

124. Jacobson, K.A.; Gao, Z.G. Adenosine receptors as therapeutic targets. Nat. Rev. Drug Discov. 2006, 5, $247-264$. [CrossRef]

125. Fredholm, B.B.; IJzerman, A.P.; Jacobson, K.A.; Klotz, K.N.; Linden, J. International Union of Pharmacology. XXV. Nomenclature and classification of adenosine receptors. Pharmacol. Rev. 2001, 53, 527-552. [PubMed]

126. Vaupel, P.; Mayer, A. Hypoxia-Driven Adenosine Accumulation: A Crucial Microenvironmental Factor Promoting Tumor Progression. Adv. Exp. Med. Biol. 2016, 876, 177-183. [CrossRef] [PubMed]

127. Vaupel, P.; Multhoff, G. Hypoxia-/HIF-1alpha-Driven Factors of the Tumor Microenvironment Impeding Antitumor Immune Responses and Promoting Malignant Progression. Adv. Exp. Med. Biol. 2018, 1072, 171-175. [CrossRef] [PubMed]

128. Busse, M.; Vaupel, P. Accumulation of purine catabolites in solid tumors exposed to therapeutic hyperthermia. Experientia 1996, 52, 469-473. [CrossRef] [PubMed]

129. Chen, Y.; Shukla, A.; Namiki, S.; Insel, P.A.; Junger, W.G. A putative osmoreceptor system that controls neutrophil function through the release of ATP, its conversion to adenosine, and activation of A2 adenosine and P2 receptors. J. Leukoc. Biol. 2004, 76, 245-253. [CrossRef] [PubMed]

130. Marquardt, D.L.; Walker, L.L.; Heinemann, S. Cloning of two adenosine receptor subtypes from mouse bone marrow-derived mast cells. J. Immunol. 1994, 152, 4508-4515.

131. Zhang, J.G.; Hepburn, L.; Cruz, G.; Borman, R.A.; Clark, K.L. The role of adenosine A2A and A2B receptors in the regulation of TNF-alpha production by human monocytes. Biochem. Pharmacol. 2005, 69, 883-889. [CrossRef]

132. Buenestado, A.; Grassin Delyle, S.; Arnould, I.; Besnard, F.; Naline, E.; Blouquit-Laye, S.; Chapelier, A.; Bellamy, J.F.; Devillier, P. The role of adenosine receptors in regulating production of tumour necrosis factor-alpha and chemokines by human lung macrophages. Br. J. Pharmacol. 2010, 159, 1304-1311. [CrossRef] 
133. Panther, E.; Idzko, M.; Herouy, Y.; Rheinen, H.; Gebicke-Haerter, P.J.; Mrowietz, U.; Dichmann, S.; Norgauer, J. Expression and function of adenosine receptors in human dendritic cells. FASEB J. 2001, 15, 1963-1970. [CrossRef]

134. Huang, S.; Apasov, S.; Koshiba, M.; Sitkovsky, M. Role of A2a extracellular adenosine receptor-mediated signaling in adenosine-mediated inhibition of T-cell activation and expansion. Blood 1997, 90, 1600-1610. [CrossRef]

135. Mirabet, M.; Herrera, C.; Cordero, O.J.; Mallol, J.; Lluis, C.; Franco, R. Expression of A2B adenosine receptors in human lymphocytes: Their role in T cell activation. J. Cell Sci. 1999, 112, 491-502. [PubMed]

136. Gessi, S.; Varani, K.; Merighi, S.; Cattabriga, E.; Avitabile, A.; Gavioli, R.; Fortini, C.; Leung, E.; Mac Lennan, S.; Borea, P.A. Expression of A3 adenosine receptors in human lymphocytes: Up-regulation in $\mathrm{T}$ cell activation. Mol. Pharmacol. 2004, 65, 711-719. [CrossRef] [PubMed]

137. Priebe, T.; Platsoucas, C.D.; Nelson, J.A. Adenosine receptors and modulation of natural killer cell activity by purine nucleosides. Cancer Res. 1990, 50, 4328-4331. [PubMed]

138. Hasko, G.; Linden, J.; Cronstein, B.; Pacher, P. Adenosine receptors: Therapeutic aspects for inflammatory and immune diseases. Nat. Rev. Drug Discov. 2008, 7, 759-770. [CrossRef]

139. Hasko, G.; Cronstein, B. Regulation of inflammation by adenosine. Front. Immunol. 2013, 4, 85. [CrossRef]

140. Fredholm, B.B.; Arslan, G.; Halldner, L.; Kull, B.; Schulte, G.; Wasserman, W. Structure and function of adenosine receptors and their genes. Naunyn-Schmiedeberg's Arch. Pharmacol. 2000, 362, 364-374. [CrossRef]

141. Chunn, J.L.; Molina, J.G.; Mi, T.; Xia, Y.; Kellems, R.E.; Blackburn, M.R. Adenosine-dependent pulmonary fibrosis in adenosine deaminase-deficient mice. J. Immunol. 2005, 175, 1937-1946. [CrossRef]

142. Volmer, J.B.; Thompson, L.F.; Blackburn, M.R. Ecto-5'-nucleotidase (CD73)-mediated adenosine production is tissue protective in a model of bleomycin-induced lung injury. J. Immunol. 2006, 176, 4449-4458. [CrossRef] [PubMed]

143. Zhou, Y.; Schneider, D.J.; Morschl, E.; Song, L.; Pedroza, M.; Karmouty-Quintana, H.; Le, T.; Sun, C.X.; Blackburn, M.R. Distinct roles for the A2B adenosine receptor in acute and chronic stages of bleomycin-induced lung injury. J. Immunol. 2011, 186, 1097-1106. [CrossRef]

144. Feoktistov, I.; Biaggioni, I.; Cronstein, B.N. Adenosine receptors in wound healing, fibrosis and angiogenesis. Handb. Exp. Pharmacol. 2009, 383-397. [CrossRef]

145. Zhao, W.; Robbins, M.E. Inflammation and chronic oxidative stress in radiation-induced late normal tissue injury: Therapeutic implications. Curr. Med. Chem. 2009, 16, 130-143. [CrossRef] [PubMed]

146. Westbury, C.B.; Yarnold, J.R. Radiation fibrosis-current clinical and therapeutic perspectives. Clin. Oncol. 2012, 24, 657-672. [CrossRef] [PubMed]

147. Guipaud, O.; Holler, V.; Buard, V.; Tarlet, G.; Royer, N.; Vinh, J.; Benderitter, M. Time-course analysis of mouse serum proteome changes following exposure of the skin to ionizing radiation. Proteomics 2007, 7, 3992-4002. [CrossRef] [PubMed]

148. Holler, V.; Buard, V.; Gaugler, M.H.; Guipaud, O.; Baudelin, C.; Sache, A.; Perez Mdel, R.; Squiban, C.; Tamarat, R.; Milliat, F.; et al. Pravastatin limits radiation-induced vascular dysfunction in the skin. J. Investig. Dermatol. 2009, 129, 1280-1291. [CrossRef] [PubMed]

149. Iwakawa, M.; Noda, S.; Ohta, T.; Ohira, C.; Lee, R.; Goto, M.; Wakabayashi, M.; Matsui, Y.; Harada, Y.; Imai, T. Different radiation susceptibility among five strains of mice detected by a skin reaction. J. Radiat. Res. 2003, 44, 7-13. [CrossRef] [PubMed]

150. Verginadis, I.I.; Kanade, R.; Bell, B.; Koduri, S.; Ben-Josef, E.; Koumenis, C. A Novel Mouse Model to Study Image-Guided, Radiation-Induced Intestinal Injury and Preclinical Screening of Radioprotectors. Cancer Res. 2017, 77, 908-917. [CrossRef]

151. Loinard, C.; Vilar, J.; Milliat, F.; Levy, B.; Benderitter, M. Monocytes/Macrophages Mobilization Orchestrate Neovascularization after Localized Colorectal Irradiation. Radiat. Res. 2017. [CrossRef]

152. Travis, E.L. The sequence of histological changes in mouse lungs after single doses of x-rays. Int. J. Radiat. Oncol. Biol. Phys. 1980, 6, 345-347. [CrossRef]

153. Travis, E.L.; Down, J.D.; Holmes, S.J.; Hobson, B. Radiation pneumonitis and fibrosis in mouse lung assayed by respiratory frequency and histology. Radiat. Res. 1980, 84, 133-143. [CrossRef]

154. Travis, E.L.; Harley, R.A.; Fenn, J.O.; Klobukowski, C.J.; Hargrove, H.B. Pathologic changes in the lung following single and multi-fraction irradiation. Int. J. Radiat. Oncol. Biol. Phys. 1977, 2, 475-490. [CrossRef] 
155. Haston, C.K.; Travis, E.L. Murine susceptibility to radiation-induced pulmonary fibrosis is influenced by a genetic factor implicated in susceptibility to bleomycin-induced pulmonary fibrosis. Cancer Res. 1997, 57, 5286-5291. [PubMed]

156. Jackson, I.L.; Baye, F.; Goswami, C.P.; Katz, B.P.; Zodda, A.; Pavlovic, R.; Gurung, G.; Winans, D.; Vujaskovic, Z Gene expression profiles among murine strains segregate with distinct differences in the progression of radiation-induced lung disease. Dis. Model. Mech. 2017, 10, 425-437. [CrossRef] [PubMed]

157. Paun, A.; Kunwar, A.; Haston, C.K. Acute adaptive immune response correlates with late radiation-induced pulmonary fibrosis in mice. Radiat. Oncol. 2015, 10, 45. [CrossRef] [PubMed]

158. Dabjan, M.B.; Buck, C.M.; Jackson, I.L.; Vujaskovic, Z.; Marples, B.; Down, J.D. A survey of changing trends in modelling radiation lung injury in mice: Bringing out the good, the bad, and the uncertain. Lab. Investig. 2016, 96, 936-949. [CrossRef]

159. Choi, C.; Lee, C.; Shin, S.W.; Kim, S.Y.; Hong, S.N.; Park, H.C. Comparison of Proton and Photon Beam Irradiation in Radiation-Induced Intestinal Injury Using a Mouse Model. Int. J. Mol. Sci. 2019, 20. [CrossRef]

160. Sorensen, B.S.; Bassler, N.; Nielsen, S.; Horsman, M.R.; Grzanka, L.; Spejlborg, H.; Swakon, J.; Olko, P.; Overgaard, J. Relative biological effectiveness (RBE) and distal edge effects of proton radiation on early damage in vivo. Acta Oncol. 2017, 56, 1387-1391. [CrossRef]

161. Steighner, R.J.; Povirk, L.F. Bleomycin-induced DNA lesions at mutational hot spots: Implications for the mechanism of double-strand cleavage. Proc. Natl. Acad. Sci. USA 1990, 87, 8350-8354. [CrossRef]

162. Moore, B.B.; Hogaboam, C.M. Murine models of pulmonary fibrosis. Am. J. Physiol. Lung Cell. Mol. Physiol. 2008, 294, L152-L160. [CrossRef]

163. Moeller, A.; Ask, K.; Warburton, D.; Gauldie, J.; Kolb, M. The bleomycin animal model: A useful tool to investigate treatment options for idiopathic pulmonary fibrosis? Int. J. Biochem. Cell Biol. 2008, 40, 362-382. [CrossRef]

164. Chua, F.; Gauldie, J.; Laurent, G.J. Pulmonary fibrosis: Searching for model answers. Am. J. Respir. Cell Mol. Biol. 2005, 33, 9-13. [CrossRef]

165. Wilson, M.S.; Wynn, T.A. Pulmonary fibrosis: Pathogenesis, etiology and regulation. Mucosal Immunol. 2009, 2, 103-121. [CrossRef] [PubMed]

166. Mancini, M.L.; Sonis, S.T. Mechanisms of cellular fibrosis associated with cancer regimen-related toxicities. Front. Pharmacol. 2014, 5, 51. [CrossRef] [PubMed]

167. Nakayama, Y.; Makino, S.; Fukuda, Y.; Min, K.Y.; Shimizu, A.; Ohsawa, N. Activation of lavage lymphocytes in lung injuries caused by radiotherapy for lung cancer. Int. J. Radiat. Oncol. Biol. Phys. 1996, 34, 459-467. [CrossRef]

168. Martin, C.; Romero, S.; Sanchez-Paya, J.; Massuti, B.; Arriero, J.M.; Hernandez, L. Bilateral lymphocytic alveolitis: A common reaction after unilateral thoracic irradiation. Eur. Respir. J. 1999, 13, 727-732. [CrossRef] [PubMed]

169. Rube, C.E.; Palm, J.; Erren, M.; Fleckenstein, J.; Konig, J.; Remberger, K.; Rube, C. Cytokine plasma levels: Reliable predictors for radiation pneumonitis? PLoS ONE 2008, 3, e2898. [CrossRef] [PubMed]

170. Lierova, A.; Jelicova, M.; Nemcova, M.; Proksova, M.; Pejchal, J.; Zarybnicka, L.; Sinkorova, Z. Cytokines and radiation-induced pulmonary injuries. J. Radiat. Res. 2018, 59, 709-753. [CrossRef]

171. Gross, N.J.; Narine, K.R.; Wade, R. Protective effect of corticosteroids on radiation pneumonitis in mice. Radiat. Res. 1988, 113, 112-119. [CrossRef]

172. Giridhar, P.; Mallick, S.; Rath, G.K.; Julka, P.K. Radiation induced lung injury: Prediction, assessment and management. Asian Pac. J. Cancer Prev. 2015, 16, 2613-2617. [CrossRef]

173. Chen, Z.; Wu, Z.; Ning, W. Advances in Molecular Mechanisms and Treatment of Radiation-Induced Pulmonary Fibrosis. Transl. Oncol. 2018, 12, 162-169. [CrossRef]

174. Ozturk, B.; Egehan, I.; Atavci, S.; Kitapci, M. Pentoxifylline in prevention of radiation-induced lung toxicity in patients with breast and lung cancer: A double-blind randomized trial. Int. J. Radiat. Oncol. Biol. Phys. 2004, 58, 213-219. [CrossRef]

175. Williams, J.P.; Johnston, C.J.; Finkelstein, J.N. Treatment for radiation-induced pulmonary late effects: Spoiled for choice or looking in the wrong direction? Curr. Drug Targets 2010, 11, 1386-1394. [CrossRef] [PubMed] 
176. McDonald, S.; Rubin, P.; Phillips, T.L.; Marks, L.B. Injury to the lung from cancer therapy: Clinical syndromes, measurable endpoints, and potential scoring systems. Int. J. Radiat. Oncol. Biol. Phys. 1995, 31, 1187-1203. [CrossRef]

177. Jackson, I.L.; Vujaskovic, Z.; Down, J.D. A further comparison of pathologies after thoracic irradiation among different mouse strains: Finding the best preclinical model for evaluating therapies directed against radiation-induced lung damage. Radiat. Res. 2011, 175, 510-518. [CrossRef] [PubMed]

178. De Ruysscher, D.; Houben, A.; Aerts, H.J.; Dehing, C.; Wanders, R.; Ollers, M.; Dingemans, A.M.; Hochstenbag, M.; Boersma, L.; Borger, J.; et al. Increased (18)F-deoxyglucose uptake in the lung during the first weeks of radiotherapy is correlated with subsequent Radiation-Induced Lung Toxicity (RILT): A prospective pilot study. Radiother. Oncol. 2009, 91, 415-420. [CrossRef] [PubMed]

179. Travis, E.L.; Rachakonda, G.; Zhou, X.; Korhonen, K.; Sekhar, K.R.; Biswas, S.; Freeman, M.L. NRF2 deficiency reduces life span of mice administered thoracic irradiation. Free Radic. Biol. Med. 2011, 51, 1175-1183. [CrossRef] [PubMed]

180. Bickelhaupt, S.; Erbel, C.; Timke, C.; Wirkner, U.; Dadrich, M.; Flechsig, P.; Tietz, A.; Pfohler, J.; Gross, W.; Peschke, P.; et al. Effects of CTGF Blockade on Attenuation and Reversal of Radiation-Induced Pulmonary Fibrosis. J. Natl. Cancer Inst. 2017, 109. [CrossRef] [PubMed]

181. Sternlicht, M.D.; Wirkner, U.; Bickelhaupt, S.; Lopez Perez, R.; Tietz, A.; Lipson, K.E.; Seeley, T.W.; Huber, P.E. Radiation-induced pulmonary gene expression changes are attenuated by the CTGF antibody Pamrevlumab. Respir. Res. 2018, 19, 14. [CrossRef] [PubMed]

182. Salvo, N.; Barnes, E.; van Draanen, J.; Stacey, E.; Mitera, G.; Breen, D.; Giotis, A.; Czarnota, G.; Pang, J.; De Angelis, C. Prophylaxis and management of acute radiation-induced skin reactions: A systematic review of the literature. Curr. Oncol. 2010, 17, 94-112.

183. Spalek, M. Chronic radiation-induced dermatitis: Challenges and solutions. Clin. Cosmet. Investig. Dermatol. 2016, 9, 473-482. [CrossRef]

184. Bray, F.N.; Simmons, B.J.; Wolfson, A.H.; Nouri, K. Acute and Chronic Cutaneous Reactions to Ionizing Radiation Therapy. Dermatol. Ther. 2016, 6, 185-206. [CrossRef]

185. Manna, B.C.J.S. Radiation Therapy, Skin (Integument) Ulcer. Available online: https://europepmc.org/books/ NBK507719; jsessionid=6C77413EBA217FDC11021341B6DA070A (accessed on 26 February 2019).

186. Amber, K.T.; Shiman, M.I.; Badiavas, E.V. The use of antioxidants in radiotherapy-induced skin toxicity. Integr. Cancer Ther. 2014, 13, 38-45. [CrossRef] [PubMed]

187. Bryant, R.A.; Nix, D.P. Acute and Chronic Wounds: Current Management Concepts; Mosby: Maryland Heights, MO, USA, 2015.

188. Iyer, S.; Balasubramanian, D. Management of radiation wounds. Indian J. Plast. Surg. 2012, 45, 325-331. [CrossRef] [PubMed]

189. Hymes, S.R.; Strom, E.A.; Fife, C. Radiation dermatitis: Clinical presentation, pathophysiology, and treatment 2006. J. Am. Acad. Dermatol. 2006, 54, 28-46. [CrossRef] [PubMed]

190. Noda, S.; Iwakawa, M.; Ohta, T.; Iwata, M.; Yang, M.; Goto, M.; Tanaka, H.; Harada, Y.; Imai, T. Inter-strain variance in late phase of erythematous reaction or leg contracture after local irradiation among three strains of mice. Cancer Detect. Prev. 2005, 29, 376-382. [CrossRef]

191. Shadad, A.K.; Sullivan, F.J.; Martin, J.D.; Egan, L.J. Gastrointestinal radiation injury: Symptoms, risk factors and mechanisms. World J. Gastroenterol. 2013, 19, 185-198. [CrossRef]

192. Mallick, S.; Madan, R.; Julka, P.K.; Rath, G.K. Radiation Induced Cystitis and Proctitis-Prediction, Assessment and Management. Asian Pac. J. Cancer Prev. 2015, 16, 5589-5594. [CrossRef]

193. Qin, Q.; Huang, Q.; Zhong, Q.; Fan, X.; Chen, D.; Wang, L. Clinical risk factors for late intestinal toxicity after radiotherapy: A systematic review protocol. Syst. Rev. 2013, 2, 39. [CrossRef] [PubMed]

194. Shadad, A.K.; Sullivan, F.J.; Martin, J.D.; Egan, L.J. Gastrointestinal radiation injury: Prevention and treatment. World J. Gastroenterol. 2013, 19, 199-208. [CrossRef]

195. Rieder, F.; Brenmoehl, J.; Leeb, S.; Scholmerich, J.; Rogler, G. Wound healing and fibrosis in intestinal disease. Gut 2007, 56, 130-139. [CrossRef]

196. Berbee, M.; Hauer-Jensen, M. Novel drugs to ameliorate gastrointestinal normal tissue radiation toxicity in clinical practice: What is emerging from the laboratory? Curr. Opin. Supportive Palliat. Care 2012, 6, 54-59. [CrossRef] 
197. Hauer-Jensen, M.; Poulakos, L.; Osborne, J.W. Effects of accelerated fractionation on radiation injury of the small intestine: A new rat model. Int. J. Radiat. Oncol. Biol. Phys. 1988, 14, 1205-1212. [CrossRef]

198. Breitz, H. Clinical aspects of radiation nephropathy. Cancer Biother. Radiopharm. 2004, 19, 359-362. [CrossRef] [PubMed]

199. Dawson, L.A.; Kavanagh, B.D.; Paulino, A.C.; Das, S.K.; Miften, M.; Li, X.A.; Pan, C.; Ten Haken, R.K.; Schultheiss, T.E. Radiation-associated kidney injury. Int. J. Radiat. Oncol. Biol. Phys. 2010, 76, S108-S115. [CrossRef]

200. Cohen, E.P.; Fish, B.L.; Moulder, J.E. Mitigation of radiation injuries via suppression of the renin-angiotensin system: Emphasis on radiation nephropathy. Curr. Drug Targets 2010, 11, 1423-1429. [CrossRef] [PubMed]

201. Langen, B.; Rudqvist, N.; Parris, T.Z.; Schuler, E.; Helou, K.; Forssell-Aronsson, E. Comparative analysis of transcriptional gene regulation indicates similar physiologic response in mouse tissues at low absorbed doses from intravenously administered 211At. J. Nucl. Med. 2013, 54, 990-998. [CrossRef] [PubMed]

202. Rudqvist, N.; Schuler, E.; Parris, T.Z.; Langen, B.; Helou, K.; Forssell-Aronsson, E. Dose-specific transcriptional responses in thyroid tissue in mice after (131)I administration. Nucl. Med. Biol. 2015, 42, 263-268. [CrossRef] [PubMed]

203. Schuler, E.; Rudqvist, N.; Parris, T.Z.; Langen, B.; Spetz, J.; Helou, K.; Forssell-Aronsson, E. Time- and dose rate-related effects of internal (177)Lu exposure on gene expression in mouse kidney tissue. Nucl. Med. Biol. 2014, 41, 825-832. [CrossRef]

204. Rudqvist, N.; Parris, T.Z.; Schuler, E.; Helou, K.; Forssell-Aronsson, E. Transcriptional response of BALB/c mouse thyroids following in vivo astatine-211 exposure reveals distinct gene expression profiles. EJNMMI Res. 2012, 2, 32. [CrossRef]

205. Schuler, E.; Larsson, M.; Parris, T.Z.; Johansson, M.E.; Helou, K.; Forssell-Aronsson, E. Potential Biomarkers for Radiation-Induced Renal Toxicity following 177Lu-Octreotate Administration in Mice. PLoS ONE 2015, 10, e0136204. [CrossRef]

206. Nieder, C.; Schnaiter, A.; Weber, W.A.; Schill, S.; Andratschke, N.; Schwaiger, M.; Molls, M. Detrimental effects of an antibody directed against tumor necrosis factor alpha in experimental kidney irradiation. Anticancer Res. 2007, 27, 2353-2357.

207. Rube, C.E.; Fricke, A.; Wendorf, J.; Stutzel, A.; Kuhne, M.; Ong, M.F.; Lipp, P.; Rube, C. Accumulation of DNA double-strand breaks in normal tissues after fractionated irradiation. Int. J. Radiat. Oncol. Biol. Phys. 2010, 76, 1206-1213. [CrossRef] [PubMed]

208. Down, J.D.; Berman, A.J.; Warhol, M.; Van Dijken, P.J.; Ferrara, J.L.; Yeap, B.; Hellman, S.; Mauch, P.M. Late tissue-specific toxicity of total body irradiation and busulfan in a murine bone marrow transplant model. Int. J. Radiat. Oncol. Biol. Phys. 1989, 17, 109-116. [CrossRef]

209. Shen, B.; Liu, X.; Fan, Y.; Qiu, J. Macrophages regulate renal fibrosis through modulating TGFbeta superfamily signaling. Inflammation 2014, 37, 2076-2084. [CrossRef] [PubMed]

210. Pan, B.; Liu, G.; Jiang, Z.; Zheng, D. Regulation of renal fibrosis by macrophage polarization. Cell. Physiol. Biochem. 2015, 35, 1062-1069. [CrossRef]

211. Chunn, J.L.; Mohsenin, A.; Young, H.W.; Lee, C.G.; Elias, J.A.; Kellems, R.E.; Blackburn, M.R. Partially adenosine deaminase-deficient mice develop pulmonary fibrosis in association with adenosine elevations. Am. J. Physiol. Lung Cell. Mol. Physiol. 2006, 290, L579-L587. [CrossRef]

212. Blackburn, M.R.; Volmer, J.B.; Thrasher, J.L.; Zhong, H.; Crosby, J.R.; Lee, J.J.; Kellems, R.E. Metabolic consequences of adenosine deaminase deficiency in mice are associated with defects in alveogenesis, pulmonary inflammation, and airway obstruction. J. Exp. Med. 2000, 192, 159-170. [CrossRef]

213. Luo, F.; Le, N.B.; Mills, T.; Chen, N.Y.; Karmouty-Quintana, H.; Molina, J.G.; Davies, J.; Philip, K.; Volcik, K.A.; Liu, H.; et al. Extracellular adenosine levels are associated with the progression and exacerbation of pulmonary fibrosis. FASEB J. 2016, 30, 874-883. [CrossRef]

214. Sun, C.X.; Zhong, H.; Mohsenin, A.; Morschl, E.; Chunn, J.L.; Molina, J.G.; Belardinelli, L.; Zeng, D.; Blackburn, M.R. Role of A2B adenosine receptor signaling in adenosine-dependent pulmonary inflammation and injury. J. Clin. Investig. 2006, 116, 2173-2182. [CrossRef]

215. Cronstein, B.N. Adenosine receptors and fibrosis: A translational review. F1000 Biol. Rep. 2011, 3, 21. [CrossRef]

216. Shaikh, G.; Cronstein, B. Signaling pathways involving adenosine A2A and A2B receptors in wound healing and fibrosis. Purinergic Signal. 2016, 12, 191-197. [CrossRef] 
217. Huang, R.; Wu, D.; Yuan, Y.; Li, X.; Holm, R.; Trope, C.G.; Nesland, J.M.; Suo, Z. CD117 expression in fibroblasts-like stromal cells indicates unfavorable clinical outcomes in ovarian carcinoma patients. PLOS ONE 2014, 9, e112209. [CrossRef] [PubMed]

218. Denu, R.A.; Nemcek, S.; Bloom, D.D.; Goodrich, A.D.; Kim, J.; Mosher, D.F.; Hematti, P. Fibroblasts and Mesenchymal Stromal/Stem Cells Are Phenotypically Indistinguishable. Acta Haematol. 2016, 136, 85-97. [CrossRef] [PubMed]

219. Synnestvedt, K.; Furuta, G.T.; Comerford, K.M.; Louis, N.; Karhausen, J.; Eltzschig, H.K.; Hansen, K.R.; Thompson, L.F.; Colgan, S.P. Ecto-5' -nucleotidase (CD73) regulation by hypoxia-inducible factor-1 mediates permeability changes in intestinal epithelia. J. Clin. Investig. 2002, 110, 993-1002. [CrossRef] [PubMed]

220. Strohmeier, G.R.; Lencer, W.I.; Patapoff, T.W.; Thompson, L.F.; Carlson, S.L.; Moe, S.J.; Carnes, D.K.; Mrsny, R.J.; Madara, J.L. Surface expression, polarization, and functional significance of CD73 in human intestinal epithelia. J. Clin. Investig. 1997, 99, 2588-2601. [CrossRef]

221. Flocke, K.; Lesch, G.; Elsasser, H.P.; Bosslet, K.; Mannherz, H.G. Monoclonal antibodies against 5'-nucleotidase from a human pancreatic tumor cell line: Their characterization and inhibitory capacity on tumor cell adhesion to fibronectin substratum. Eur. J. Cell Biol. 1992, 58, 62-70.

222. Kruger, K.H.; Thompson, L.F.; Kaufmann, M.; Moller, P. Expression of ecto-5'-nucleotidase (CD73) in normal mammary gland and in breast carcinoma. Br. J. Cancer 1991, 63, 114-118. [CrossRef]

223. Fernandez, P.; Trzaska, S.; Wilder, T.; Chiriboga, L.; Blackburn, M.R.; Cronstein, B.N.; Chan, E.S. Pharmacological blockade of A2A receptors prevents dermal fibrosis in a model of elevated tissue adenosine. Am. J. Pathol. 2008, 172, 1675-1682. [CrossRef]

224. Fernandez, P.; Perez-Aso, M.; Smith, G.; Wilder, T.; Trzaska, S.; Chiriboga, L.; Franks, A., Jr.; Robson, S.C.; Cronstein, B.N.; Chan, E.S. Extracellular generation of adenosine by the ectonucleotidases CD39 and CD73 promotes dermal fibrosis. Am. J. Pathol. 2013, 183, 1740-1746. [CrossRef]

225. Lazzerini, P.E.; Natale, M.; Gianchecchi, E.; Capecchi, P.L.; Montilli, C.; Zimbone, S.; Castrichini, M.; Balistreri, E.; Ricci, G.; Selvi, E.; et al. Adenosine A2A receptor activation stimulates collagen production in sclerodermic dermal fibroblasts either directly and through a cross-talk with the cannabinoid system. J. Mol. Med. 2012, 90, 331-342. [CrossRef]

226. Karmouty-Quintana, H.; Philip, K.; Acero, L.F.; Chen, N.Y.; Weng, T.; Molina, J.G.; Luo, F.; Davies, J.; Le, N.B.; Bunge, I.; et al. Deletion of ADORA2B from myeloid cells dampens lung fibrosis and pulmonary hypertension. FASEB J. 2015, 29, 50-60. [CrossRef]

227. Karmouty-Quintana, H.; Zhong, H.; Acero, L.; Weng, T.; Melicoff, E.; West, J.D.; Hemnes, A.; Grenz, A.; Eltzschig, H.K.; Blackwell, T.S.; et al. The A2B adenosine receptor modulates pulmonary hypertension associated with interstitial lung disease. FASEB J. 2012, 26, 2546-2557. [CrossRef] [PubMed]

228. Zhang, W.; Zhang, Y.; Wang, W.; Dai, Y.; Ning, C.; Luo, R.; Sun, K.; Glover, L.; Grenz, A.; Sun, H.; et al. Elevated ecto- $5^{\prime}$-nucleotidase-mediated increased renal adenosine signaling via A2B adenosine receptor contributes to chronic hypertension. Circ. Res. 2013, 112, 1466-1478. [CrossRef]

229. Karmouty-Quintana, H.; Weng, T.; Garcia-Morales, L.J.; Chen, N.Y.; Pedroza, M.; Zhong, H.; Molina, J.G.; Bunge, R.; Bruckner, B.A.; Xia, Y.; et al. Adenosine A2B receptor and hyaluronan modulate pulmonary hypertension associated with chronic obstructive pulmonary disease. Am. J. Respir. Cell Mol. Biol. 2013, 49, 1038-1047. [CrossRef] [PubMed]

230. Chan, E.S.; Fernandez, P.; Merchant, A.A.; Montesinos, M.C.; Trzaska, S.; Desai, A.; Tung, C.F.; Khoa, D.N.; Pillinger, M.H.; Reiss, A.B.; et al. Adenosine A2A receptors in diffuse dermal fibrosis: Pathogenic role in human dermal fibroblasts and in a murine model of scleroderma. Arthritis Rheum. 2006, 54, 2632-2642. [CrossRef] [PubMed]

231. Chen, Y.; Epperson, S.; Makhsudova, L.; Ito, B.; Suarez, J.; Dillmann, W.; Villarreal, F. Functional effects of enhancing or silencing adenosine A2b receptors in cardiac fibroblasts. Am. J. Physiol. Heart Circ. Physiol. 2004, 287, H2478-H2486. [CrossRef] [PubMed]

232. Factor, P.; Mutlu, G.M.; Chen, L.; Mohameed, J.; Akhmedov, A.T.; Meng, F.J.; Jilling, T.; Lewis, E.R.; Johnson, M.D.; Xu, A.; et al. Adenosine regulation of alveolar fluid clearance. Proc. Natl. Acad. Sci. USA 2007, 104, 4083-4088. [CrossRef]

233. Boison, D.; Chen, J.F.; Fredholm, B.B. Adenosine signaling and function in glial cells. Cell Death Differ. 2010, 17, 1071-1082. [CrossRef] 
234. Abbracchio, M.P.; Burnstock, G.; Verkhratsky, A.; Zimmermann, H. Purinergic signalling in the nervous system: An overview. Trends Neurosci. 2009, 32, 19-29. [CrossRef]

235. Boison, D. Adenosinergic signaling in epilepsy. Neuropharmacology 2016, 104, 131-139. [CrossRef]

236. Kiese, K.; Jablonski, J.; Boison, D.; Kobow, K. Dynamic Regulation of the Adenosine Kinase Gene during Early Postnatal Brain Development and Maturation. Front. Mol. Neurosci. 2016, 9, 99. [CrossRef]

237. Weltha, L.; Reemmer, J.; Boison, D. The role of adenosine in epilepsy. Brain Res. Bull. 2019, 151, 46-54. [CrossRef] [PubMed]

238. Acharya, M.M.; Baulch, J.E.; Lusardi, T.A.; Allen, B.D.; Chmielewski, N.N.; Baddour, A.A.D.; Limoli, C.L.; Boison, D. Corrigendum: Adenosine Kinase Inhibition Protects against Cranial Radiation-Induced Cognitive Dysfunction. Front. Mol. Neurosci. 2017, 10, 218. [CrossRef] [PubMed]

239. Acharya, M.M.; Baulch, J.E.; Lusardi, T.A.; Allen, B.D.; Chmielewski, N.N.; Baddour, A.A.; Limoli, C.L.; Boison, D. Adenosine Kinase Inhibition Protects against Cranial Radiation-Induced Cognitive Dysfunction. Front. Mol. Neurosci. 2016, 9, 42. [CrossRef] [PubMed]

240. Li, T.; Quan Lan, J.; Fredholm, B.B.; Simon, R.P.; Boison, D. Adenosine dysfunction in astrogliosis: Cause for seizure generation? Neuron Glia Biol. 2007, 3, 353-366. [CrossRef] [PubMed]

241. Boison, D. Adenosine dysfunction in epilepsy. Glia 2012, 60, 1234-1243. [CrossRef] [PubMed]

242. Wahlman, C.; Doyle, T.M.; Little, J.W.; Luongo, L.; Janes, K.; Chen, Z.; Esposito, E.; Tosh, D.K.; Cuzzocrea, S.; Jacobson, K.A.; et al. Chemotherapy-induced pain is promoted by enhanced spinal adenosine kinase levels through astrocyte-dependent mechanisms. Pain 2018, 159, 1025-1034. [CrossRef]

243. De Leve, S.; Wirsdorfer, F.; Cappuccini, F.; Schutze, A.; Meyer, A.V.; Rock, K.; Thompson, L.F.; Fischer, J.W.; Stuschke, M.; Jendrossek, V. Loss of CD73 prevents accumulation of alternatively activated macrophages and the formation of prefibrotic macrophage clusters in irradiated lungs. FASEB J. 2017, 31, 2869-2880. [CrossRef]

244. De Leve, S.; Wirsdorfer, F.; Jendrossek, V. Targeting the Immunomodulatory CD73/Adenosine System to Improve the Therapeutic Gain of Radiotherapy. Front. Immunol. 2019, 10, 698. [CrossRef]

245. Feig, J.L.; Mediero, A.; Corciulo, C.; Liu, H.; Zhang, J.; Perez-Aso, M.; Picard, L.; Wilder, T.; Cronstein, B. The antiviral drug tenofovir, an inhibitor of Pannexin-1-mediated ATP release, prevents liver and skin fibrosis by downregulating adenosine levels in the liver and skin. PLOS ONE 2017, 12, e0188135. [CrossRef]

246. Katebi, M.; Fernandez, P.; Chan, E.S.; Cronstein, B.N. Adenosine A2A receptor blockade or deletion diminishes fibrocyte accumulation in the skin in a murine model of scleroderma, bleomycin-induced fibrosis. Inflammation 2008, 31, 299-303. [CrossRef]

247. Zhang, J.; Corciulo, C.; Liu, H.; Wilder, T.; Ito, M.; Cronstein, B. Adenosine A2a Receptor Blockade Diminishes Wnt/beta-Catenin Signaling in a Murine Model of Bleomycin-Induced Dermal Fibrosis. Am. J. Pathol. 2017, 187, 1935-1944. [CrossRef] [PubMed]

248. Karmouty-Quintana,H.; Molina, J.G.; Philip, K.; Bellocchi, C.; Gudenkauf, B.; Wu, M.; Chen, N.Y.; Collum, S.D.; Ko, J.; Agarwal, S.K.; et al. The Antifibrotic Effect of A2B Adenosine Receptor Antagonism in a Mouse Model of Dermal Fibrosis. Arthritis Rheumatol. 2018. [CrossRef] [PubMed]

249. Colgan, S.P.; Fennimore, B.; Ehrentraut, S.F. Adenosine and gastrointestinal inflammation. J. Mol. Med. 2013, 91, 157-164. [CrossRef] [PubMed]

250. Hart, M.L.; Grenz, A.; Gorzolla, I.C.; Schittenhelm, J.; Dalton, J.H.; Eltzschig, H.K. Hypoxia-inducible factor-1alpha-dependent protection from intestinal ischemia/reperfusion injury involves ecto-5' -nucleotidase (CD73) and the A2B adenosine receptor. J. Immunol. 2011, 186, 4367-4374. [CrossRef] [PubMed]

251. Eltzschig, H.K.; Bonney, S.K.; Eckle, T. Attenuating myocardial ischemia by targeting A2B adenosine receptors. Trends Mol. Med. 2013, 19, 345-354. [CrossRef]

252. Eckle, T.; Krahn, T.; Grenz, A.; Kohler, D.; Mittelbronn, M.; Ledent, C.; Jacobson, M.A.; Osswald, H.; Thompson, L.F.; Unertl, K.; et al. Cardioprotection by ecto-5'-nucleotidase (CD73) and A2B adenosine receptors. Circulation 2007, 115, 1581-1590. [CrossRef]

253. Odashima, M.; Bamias, G.; Rivera-Nieves, J.; Linden, J.; Nast, C.C.; Moskaluk, C.A.; Marini, M.; Sugawara, K.; Kozaiwa, K.; Otaka, M.; et al. Activation of A2A adenosine receptor attenuates intestinal inflammation in animal models of inflammatory bowel disease. Gastroenterology 2005, 129, 26-33. [CrossRef]

254. Ren, T.; Tian, T.; Feng, X.; Ye, S.; Wang, H.; Wu, W.; Qiu, Y.; Yu, C.; He, Y.; Zeng, J.; et al. An adenosine A3 receptor agonist inhibits DSS-induced colitis in mice through modulation of the NF-kappaB signaling pathway. Sci. Rep. 2015, 5, 9047. [CrossRef] 
255. Ren, T.; Grants, I.; Alhaj, M.; McKiernan, M.; Jacobson, M.; Hassanain, H.H.; Frankel, W.; Wunderlich, J.; Christofi, F.L. Impact of disrupting adenosine A3 receptors (A3 $\left.{ }^{-/-} \mathrm{AR}\right)$ on colonic motility or progression of colitis in the mouse. Inflamm. Bowel Dis. 2011, 17, 1698-1713. [CrossRef]

256. Grenz, A.; Zhang, H.; Eckle, T.; Mittelbronn, M.; Wehrmann, M.; Kohle, C.; Kloor, D.; Thompson, L.F.; Osswald, H.; Eltzschig, H.K. Protective role of ecto-5'-nucleotidase (CD73) in renal ischemia. J. Am. Soc. Nephrol. 2007, 18, 833-845. [CrossRef]

257. Sung, S.J.; Li, L.; Huang, L.; Lawler, J.; Ye, H.; Rosin, D.L.; Vincent, I.S.; Le, T.H.; Yu, J.; Gorldt, N.; et al. Proximal Tubule CD73 Is Critical in Renal Ischemia-Reperfusion Injury Protection. J. Am. Soc. Nephrol. 2017, 28, 888-902. [CrossRef] [PubMed]

258. Rajakumar, S.V.; Lu, B.; Crikis, S.; Robson, S.C.; D’Apice, A.J.; Cowan, P.J.; Dwyer, K.M. Deficiency or inhibition of CD73 protects in mild kidney ischemia-reperfusion injury. Transplantation 2010, 90, 1260-1264. [CrossRef] [PubMed]

259. Jian, R.; Sun, Y.; Wang, Y.; Yu, J.; Zhong, L.; Zhou, P. CD73 protects kidney from ischemia-reperfusion injury through reduction of free radicals. Acta Pathol. Microbiol. Immunol. Scand. 2012, 120, 130-138. [CrossRef] [PubMed]

260. Day, Y.J.; Huang, L.; McDuffie, M.J.; Rosin, D.L.; Ye, H.; Chen, J.F.; Schwarzschild, M.A.; Fink, J.S.; Linden, J.; Okusa, M.D. Renal protection from ischemia mediated by A2A adenosine receptors on bone marrow-derived cells. J. Clin. Investig. 2003, 112, 883-891. [CrossRef]

261. Boison, D.; Aronica, E. Comorbidities in Neurology: Is adenosine the common link? Neuropharmacology 2015, 97, 18-34. [CrossRef]

262. Niemela, J.; Ifergan, I.; Yegutkin, G.G.; Jalkanen, S.; Prat, A.; Airas, L. IFN-beta regulates CD73 and adenosine expression at the blood-brain barrier. Eur. J. Immunol. 2008, 38, 2718-2726. [CrossRef]

263. Airas, L.; Niemela, J.; Yegutkin, G.; Jalkanen, S. Mechanism of action of IFN-beta in the treatment of multiple sclerosis: A special reference to CD73 and adenosine. Ann. N. Y. Acad. Sci. 2007, 1110, 641-648. [CrossRef]

264. Peng, Z.; Fernandez, P.; Wilder, T.; Yee, H.; Chiriboga, L.; Chan, E.S.; Cronstein, B.N. Ecto-5'-nucleotidase (CD73) -mediated extracellular adenosine production plays a critical role in hepatic fibrosis. FASEB J. 2008, 22, 2263-2272. [CrossRef]

265. Ratech, H.; Greco, M.A.; Gallo, G.; Rimoin, D.L.; Kamino, H.; Hirschhorn, R. Pathologic findings in adenosine deaminase-deficient severe combined immunodeficiency. I. Kidney, adrenal, and chondro-osseous tissue alterations. Am. J. Pathol. 1985, 120, 157-169.

266. Ozsahin, H.; Arredondo-Vega, F.X.; Santisteban, I.; Fuhrer, H.; Tuchschmid, P.; Jochum, W.; Aguzzi, A.; Lederman, H.M.; Fleischman, A.; Winkelstein, J.A.; et al. Adenosine deaminase deficiency in adults. Blood 1997, 89, 2849-2855. [CrossRef]

267. Flinn, A.M.; Gennery, A.R. Adenosine deaminase deficiency: A review. Orphanet J. Rare Dis. 2018, 13, 65. [CrossRef] [PubMed]

268. Driver, A.G.; Kukoly, C.A.; Ali, S.; Mustafa, S.J. Adenosine in bronchoalveolar lavage fluid in asthma. Am. Rev. Respir. Dis. 1993, 148, 91-97. [CrossRef] [PubMed]

269. Groves, A.M.; Johnston, C.J.; Williams, J.P.; Finkelstein, J.N. Role of Infiltrating Monocytes in the Development of Radiation-Induced Pulmonary Fibrosis. Radiat. Res. 2018, 189, 300-311. [CrossRef] [PubMed]

270. Meziani, L.; Mondini, M.; Petit, B.; Boissonnas, A.; Thomas de Montpreville, V.; Mercier, O.; Vozenin, M.C.; Deutsch, E. CSF1R inhibition prevents radiation pulmonary fibrosis by depletion of interstitial macrophages. Eur. Respir. J. 2018, 51. [CrossRef] [PubMed]

271. Scharpfenecker, M.; Floot, B.; Russell, N.S.; Stewart, F.A. The TGF-beta co-receptor endoglin regulates macrophage infiltration and cytokine production in the irradiated mouse kidney. Radiother. Oncol. 2012, 105, 313-320. [CrossRef] [PubMed]

272. Groves, A.M.; Johnston, C.J.; Misra, R.S.; Williams, J.P.; Finkelstein, J.N. Whole-Lung Irradiation Results in Pulmonary Macrophage Alterations that are Subpopulation and Strain Specific. Radiat. Res. 2015, 184, 639-649. [CrossRef]

273. Gibbons, M.A.; MacKinnon, A.C.; Ramachandran, P.; Dhaliwal, K.; Duffin, R.; Phythian-Adams, A.T.; van Rooijen, N.; Haslett, C.; Howie, S.E.; Simpson, A.J.; et al. Ly6Chi monocytes direct alternatively activated profibrotic macrophage regulation of lung fibrosis. Am. J. Respir. Crit. Care Med. 2011, 184, 569-581. [CrossRef] 
274. Wynn, T.A.; Vannella, K.M. Macrophages in Tissue Repair, Regeneration, and Fibrosis. Immunity 2016, 44, 450-462. [CrossRef]

275. Nawroth, I.; Alsner, J.; Deleuran, B.W.; Dagnaes-Hansen, F.; Yang, C.; Horsman, M.R.; Overgaard, J.; Howard, K.A.; Kjems, J.; Gao, S. Peritoneal macrophages mediated delivery of chitosan/siRNA nanoparticle to the lesion site in a murine radiation-induced fibrosis model. Acta Oncol. 2013, 52, 1730-1738. [CrossRef]

276. Horton, J.A.; Hudak, K.E.; Chung, E.J.; White, A.O.; Scroggins, B.T.; Burkeen, J.F.; Citrin, D.E. Mesenchymal stem cells inhibit cutaneous radiation-induced fibrosis by suppressing chronic inflammation. Stem Cells 2013, 31, 2231-2241. [CrossRef]

277. Liao, W.; Hei, T.K.; Cheng, S.K. Radiation-Induced Dermatitis is Mediated by IL17-Expressing gammadelta T Cells. Radiat. Res. 2017, 187, 454-464. [CrossRef] [PubMed]

278. Wirsdorfer, F.; Jendrossek, V. The Role of Lymphocytes in Radiotherapy-Induced Adverse Late Effects in the Lung. Front. Immunol. 2016, 7, 591. [CrossRef] [PubMed]

279. Ohta, A.; Kini, R.; Ohta, A.; Subramanian, M.; Madasu, M.; Sitkovsky, M. The development and immunosuppressive functions of $\mathrm{CD}^{+}{ }^{+} \mathrm{CD} 25^{+} \mathrm{FoxP}^{+}$regulatory $\mathrm{T}$ cells are under influence of the adenosine-A2A adenosine receptor pathway. Front. Immunol. 2012, 3, 190. [CrossRef] [PubMed]

280. Ohta, A.; Sitkovsky, M. Extracellular adenosine-mediated modulation of regulatory T cells. Front. Immunol. 2014, 5, 304. [CrossRef] [PubMed]

281. Prochazkova, J.; Fric, J.; Pokorna, K.; Neuwirth, A.; Krulova, M.; Zajicova, A.; Holan, V. Distinct regulatory roles of transforming growth factor-beta and interleukin-4 in the development and maintenance of natural and induced $\mathrm{CD}^{+}{ }^{+} \mathrm{CD}_{2}{ }^{+}$Foxp3 ${ }^{+}$regulatory T cells. Immunology 2009, 128, e670-e678. [CrossRef]

282. Khalil, N.; Bereznay, O.; Sporn, M.; Greenberg, A.H. Macrophage production of transforming growth factor beta and fibroblast collagen synthesis in chronic pulmonary inflammation. J. Exp. Med. 1989, 170, 727-737. [CrossRef]

283. Kumar, R.K.; O'Grady, R.; Maronese, S.E.; Wilson, M.R. Epithelial cell-derived transforming growth factor-beta in bleomycin-induced pulmonary injury. Int. J. Exp. Pathol. 1996, 77, 99-107. [CrossRef]

284. Rube, C.E.; Uthe, D.; Schmid, K.W.; Richter, K.D.; Wessel, J.; Schuck, A.; Willich, N.; Rube, C. Dose-dependent induction of transforming growth factor beta (TGF-beta) in the lung tissue of fibrosis-prone mice after thoracic irradiation. Int. J. Radiat. Oncol. Biol. Phys. 2000, 47, 1033-1042. [CrossRef]

285. Liu, F.; Liu, J.; Weng, D.; Chen, Y.; Song, L.; He, Q.; Chen, J. CD4 ${ }^{+} \mathrm{CD} 25^{+}$Foxp $3^{+}$regulatory T cells depletion may attenuate the development of silica-induced lung fibrosis in mice. PLoS ONE 2010, 5, e15404. [CrossRef]

286. Lo Re, S.; Lecocq, M.; Uwambayinema, F.; Yakoub, Y.; Delos, M.; Demoulin, J.B.; Lucas, S.; Sparwasser, T.; Renauld, J.C.; Lison, D.; et al. Platelet-derived growth factor-producing CD4 ${ }^{+}$Foxp $^{+}$regulatory T lymphocytes promote lung fibrosis. Am. J. Respir. Crit. Care Med. 2011, 184, 1270-1281. [CrossRef]

287. Regateiro, F.S.; Howie, D.; Nolan, K.F.; Agorogiannis, E.I.; Greaves, D.R.; Cobbold, S.P.; Waldmann, H. Generation of anti-inflammatory adenosine by leukocytes is regulated by TGF-beta. Eur. J. Immunol. 2011, 41, 2955-2965. [CrossRef]

288. Regateiro, F.S.; Chen, Y.; Kendal, A.R.; Hilbrands, R.; Adams, E.; Cobbold, S.P.; Ma, J.; Andersen, K.G.; Betz, A.G.; Zhang, M.; et al. Foxp3 expression is required for the induction of therapeutic tissue tolerance. J. Immunol. 2012, 189, 3947-3956. [CrossRef] [PubMed]

289. Birjandi, S.Z.; Palchevskiy, V.; Xue, Y.Y.; Nunez, S.; Kern, R.; Weigt, S.S.; Lynch, J.P., 3rd; Chatila, T.A.; Belperio, J.A. CD $4^{+}$CD25 $5^{\text {hi }}$ Foxp3 ${ }^{+}$Cells Exacerbate Bleomycin-Induced Pulmonary Fibrosis. Am. J. Pathol. 2016, 186, 2008-2020. [CrossRef] [PubMed]

290. Xiong, S.; Guo, R.; Yang, Z.; Xu, L.; Du, L.; Li, R.; Xiao, F.; Wang, Q.; Zhu, M.; Pan, X. Treg depletion attenuates irradiation-induced pulmonary fibrosis by reducing fibrocyte accumulation, inducing Th17 response, and shifting IFN-gamma, IL-12/IL-4, IL-5 balance. Immunobiology 2015, 220, 1284-1291. [CrossRef] [PubMed]

291. Epperly, M.W.; Guo, H.; Gretton, J.E.; Greenberger, J.S. Bone marrow origin of myofibroblasts in irradiation pulmonary fibrosis. Am. J. Respir. Cell Mol. Biol. 2003, 29, 213-224. [CrossRef] [PubMed]

292. Epperly, M.W.; Gretton, J.E.; Sikora, C.A.; Jefferson, M.; Bernarding, M.; Nie, S.; Greenberger, J.S. Mitochondrial localization of superoxide dismutase is required for decreasing radiation-induced cellular damage. Radiat. Res. 2003, 160, 568-578. [CrossRef] [PubMed]

293. Kim, J.H.; Jenrow, K.A.; Brown, S.L. Mechanisms of radiation-induced normal tissue toxicity and implications for future clinical trials. Radiat. Oncol. J. 2014, 32, 103-115. [CrossRef] [PubMed] 
294. Scott, C.L.; Henri, S.; Guilliams, M. Mononuclear phagocytes of the intestine, the skin, and the lung. Immunol. Rev. 2014, 262, 9-24. [CrossRef]

295. Vaupel, P.; Multhoff, G. Adenosine can thwart antitumor immune responses elicited by radiotherapy: Therapeutic strategies alleviating protumor ADO activities. Strahlentherapie und Onkologie 2016, 192, $279-287$. [CrossRef]

296. Ohta, A.; Gorelik, E.; Prasad, S.J.; Ronchese, F.; Lukashev, D.; Wong, M.K.; Huang, X.; Caldwell, S.; Liu, K.; Smith, P.; et al. A2A adenosine receptor protects tumors from antitumor T cells. Proc. Natl. Acad. Sci. USA 2006, 103, 13132-13137. [CrossRef]

297. Sitkovsky, M.V.; Kjaergaard, J.; Lukashev, D.; Ohta, A. Hypoxia-adenosinergic immunosuppression: Tumor protection by $\mathrm{T}$ regulatory cells and cancerous tissue hypoxia. Clin. Cancer Res. 2008, 14, 5947-5952. [CrossRef] [PubMed]

298. Sitkovsky, M.V.; Hatfield, S.; Abbott, R.; Belikoff, B.; Lukashev, D.; Ohta, A. Hostile, hypoxia-A2-adenosinergic tumor biology as the next barrier to overcome for tumor immunologists. Cancer Immunol. Res. 2014, 2, 598-605. [CrossRef] [PubMed]

299. Spychala, J. Tumor-promoting functions of adenosine. Pharmacol. Ther. 2000, 87, 161-173. [CrossRef]

300. Allard, B.; Turcotte, M.; Stagg, J. CD73-generated adenosine: Orchestrating the tumor-stroma interplay to promote cancer growth. J. Biomed. Biotechnol. 2012, 2012, 485156. [CrossRef] [PubMed]

301. Inoue, Y.; Yoshimura, K.; Kurabe, N.; Kahyo, T.; Kawase, A.; Tanahashi, M.; Ogawa, H.; Inui, N.; Funai, K.; Shinmura, K.; et al. Prognostic impact of CD73 and A2A adenosine receptor expression in non-small-cell lung cancer. Oncotarget 2017, 8, 8738-8751. [CrossRef] [PubMed]

302. Loi, S.; Pommey, S.; Haibe-Kains, B.; Beavis, P.A.; Darcy, P.K.; Smyth, M.J.; Stagg, J. CD73 promotes anthracycline resistance and poor prognosis in triple negative breast cancer. Proc. Natl. Acad. Sci. USA 2013, 110, 11091-11096. [CrossRef] [PubMed]

303. Ren, Z.H.; Lin, C.Z.; Cao, W.; Yang, R.; Lu, W.; Liu, Z.Q.; Chen, Y.M.; Yang, X.; Tian, Z.; Wang, L.Z.; et al. CD73 is associated with poor prognosis in HNSCC. Oncotarget 2016, 7, 61690-61702. [CrossRef]

304. Buisseret, L.; Pommey, S.; Allard, B.; Garaud, S.; Bergeron, M.; Cousineau, I.; Ameye, L.; Bareche, Y.; Paesmans, M.; Crown, J.P.A.; et al. Clinical significance of CD73 in triple-negative breast cancer: Multiplex analysis of a phase III clinical trial. Ann. Oncol. 2018, 29, 1056-1062. [CrossRef]

305. Turcotte, M.; Allard, D.; Mittal, D.; Bareche, Y.; Buisseret, L.; Jose, V.; Pommey, S.; Delisle, V.; Loi, S.; Joensuu, H.; et al. CD73 Promotes Resistance to HER2/ErbB2 Antibody Therapy. Cancer Res. 2017, 77, 5652-5663. [CrossRef]

306. Stagg, J.; Divisekera, U.; Duret, H.; Sparwasser, T.; Teng, M.W.; Darcy, P.K.; Smyth, M.J. CD73-deficient mice have increased antitumor immunity and are resistant to experimental metastasis. Cancer Res. 2011, 71, 2892-2900. [CrossRef]

307. Stagg, J.; Smyth, M.J. Extracellular adenosine triphosphate and adenosine in cancer. Oncogene 2010, 29, 5346-5358. [CrossRef]

308. Wang, L.; Fan, J.; Thompson, L.F.; Zhang, Y.; Shin, T.; Curiel, T.J.; Zhang, B. CD73 has distinct roles in nonhematopoietic and hematopoietic cells to promote tumor growth in mice. J. Clin. Investig. 2011, 121, 2371-2382. [CrossRef]

309. Mittal, D.; Sinha, D.; Barkauskas, D.; Young, A.; Kalimutho, M.; Stannard, K.; Caramia, F.; Haibe-Kains, B.; Stagg, J.; Khanna, K.K.; et al. Adenosine 2B Receptor Expression on Cancer Cells Promotes Metastasis. Cancer Res. 2016, 76, 4372-4382. [CrossRef]

310. Young, A.; Mittal, D.; Stagg, J.; Smyth, M.J. Targeting cancer-derived adenosine: New therapeutic approaches. Cancer Discov. 2014, 4, 879-888. [CrossRef]

311. Stagg, J.; Beavis, P.A.; Divisekera, U.; Liu, M.C.; Moller, A.; Darcy, P.K.; Smyth, M.J. CD73-deficient mice are resistant to carcinogenesis. Cancer Res. 2012, 72, 2190-2196. [CrossRef]

312. Yegutkin, G.G.; Marttila-Ichihara, F.; Karikoski, M.; Niemela, J.; Laurila, J.P.; Elima, K.; Jalkanen, S.; Salmi, M. Altered purinergic signaling in CD73-deficient mice inhibits tumor progression. Eur. J. Immunol. 2011, 41, 1231-1241. [CrossRef]

313. Stagg, J.; Divisekera, U.; McLaughlin, N.; Sharkey, J.; Pommey, S.; Denoyer, D.; Dwyer, K.M.; Smyth, M.J. Anti-CD73 antibody therapy inhibits breast tumor growth and metastasis. Proc. Natl. Acad. Sci. USA 2010, 107, 1547-1552. [CrossRef] 
314. Young, A.; Ngiow, S.F.; Madore, J.; Reinhardt, J.; Landsberg, J.; Chitsazan, A.; Rautela, J.; Bald, T.; Barkauskas, D.S.; Ahern, E.; et al. Targeting Adenosine in BRAF-Mutant Melanoma Reduces Tumor Growth and Metastasis. Cancer Res. 2017, 77, 4684-4696. [CrossRef]

315. Leth-Larsen, R.; Lund, R.; Hansen, H.V.; Laenkholm, A.V.; Tarin, D.; Jensen, O.N.; Ditzel, H.J. Metastasis-related plasma membrane proteins of human breast cancer cells identified by comparative quantitative mass spectrometry. Mol. Cell. Proteom. 2009, 8, 1436-1449. [CrossRef]

316. Monteiro, I.; Vigano, S.; Faouzi, M.; Treilleux, I.; Michielin, O.; Menetrier-Caux, C.; Caux, C.; Romero, P.; de Leval, L. CD73 expression and clinical significance in human metastatic melanoma. Oncotarget 2018, 9, 26659-26669. [CrossRef]

317. Reinhardt, J.; Landsberg, J.; Schmid-Burgk, J.L.; Ramis, B.B.; Bald, T.; Glodde, N.; Lopez-Ramos, D.; Young, A.; Ngiow, S.F.; Nettersheim, D.; et al. MAPK Signaling and Inflammation Link Melanoma Phenotype Switching to Induction of CD73 during Immunotherapy. Cancer Res. 2017, 77, 4697-4709. [CrossRef]

318. Hoskin, D.W.; Reynolds, T.; Blay, J. Adenosine as a possible inhibitor of killer T-cell activation in the microenvironment of solid tumours. Int. J. Cancer 1994, 59, 854-855. [CrossRef]

319. Sitkovsky, M.V. T regulatory cells: Hypoxia-adenosinergic suppression and re-direction of the immune response. Trends Immunol. 2009, 30, 102-108. [CrossRef]

320. Li, J.; Wang, L.; Chen, X.; Li, L.; Li, Y.; Ping, Y.; Huang, L.; Yue, D.; Zhang, Z.; Wang, F.; et al. CD39/CD73 upregulation on myeloid-derived suppressor cells via TGF-beta-mTOR-HIF-1 signaling in patients with non-small cell lung cancer. Oncoimmunology 2017, 6, e1320011. [CrossRef]

321. Li, L.; Wang, L.; Li, J.; Fan, Z.; Yang, L.; Zhang, Z.; Zhang, C.; Yue, D.; Qin, G.; Zhang, T.; et al. Metformin-Induced Reduction of CD39 and CD73 Blocks Myeloid-Derived Suppressor Cell Activity in Patients with Ovarian Cancer. Cancer Res. 2018, 78, 1779-1791. [CrossRef]

322. Chen, S.; Fan, J.; Zhang, M.; Qin, L.; Dominguez, D.; Long, A.; Wang, G.; Ma, R.; Li, H.; Zhang, Y.; et al. CD73 expression on effector $\mathrm{T}$ cells sustained by TGF-beta facilitates tumor resistance to anti-4-1BB/CD137 therapy. Nat. Commun. 2019, 10, 150. [CrossRef]

323. Allard, D.; Chrobak, P.; Allard, B.; Messaoudi, N.; Stagg, J. Targeting the CD73-adenosine axis in immuno-oncology. Immunol. Lett. 2019, 205, 31-39. [CrossRef]

324. Antonioli, L.; Blandizzi, C.; Pacher, P.; Hasko, G. Immunity, inflammation and cancer: A leading role for adenosine. Nat. Rev. Cancer 2013, 13, 842-857. [CrossRef]

325. Leone, R.D.; Emens, L.A. Targeting adenosine for cancer immunotherapy. J. Immunother. Cancer $2018,6,57$. [CrossRef]

326. Vigano, S.; Alatzoglou, D.; Irving, M.; Menetrier-Caux, C.; Caux, C.; Romero, P.; Coukos, G. Targeting Adenosine in Cancer Immunotherapy to Enhance T-Cell Function. Front. Immunol. 2019, 10, 925. [CrossRef]

327. Allard, B.; Pommey, S.; Smyth, M.J.; Stagg, J. Targeting CD73 enhances the antitumor activity of anti-PD-1 and anti-CTLA-4 mAbs. Clin. Cancer Res. 2013, 19, 5626-5635. [CrossRef]

328. Young, A.; Ngiow, S.F.; Barkauskas, D.S.; Sult, E.; Hay, C.; Blake, S.J.; Huang, Q.; Liu, J.; Takeda, K.; Teng, M.W.L.; et al. Co-inhibition of CD73 and A2AR Adenosine Signaling Improves Anti-tumor Immune Responses. Cancer Cell 2016, 30, 391-403. [CrossRef]

329. Hay, C.M.; Sult, E.; Huang, Q.; Mulgrew, K.; Fuhrmann, S.R.; McGlinchey, K.A.; Hammond, S.A.; Rothstein, R.; Rios-Doria, J.; Poon, E.; et al. Targeting CD73 in the tumor microenvironment with MEDI9447. Oncoimmunology 2016, 5, e1208875. [CrossRef]

330. Mittal, D.; Young, A.; Stannard, K.; Yong, M.; Teng, M.W.; Allard, B.; Stagg, J.; Smyth, M.J. Antimetastatic effects of blocking PD-1 and the adenosine A2A receptor. Cancer Res. 2014, 74, 3652-3658. [CrossRef]

331. Deng, W.W.; Li, Y.C.; Ma, S.R.; Mao, L.; Yu, G.T.; Bu, L.L.; Kulkarni, A.B.; Zhang, W.F.; Sun, Z.J. Specific blockade CD73 alters the "exhausted" phenotype of T cells in head and neck squamous cell carcinoma. Int. J. Cancer 2018, 143, 1494-1504. [CrossRef]

332. Vijayan, D.; Barkauskas, D.S.; Stannard, K.; Sult, E.; Buonpane, R.; Takeda, K.; Teng, M.W.L.; Sachsenmeier, K.; Hay, C.; Smyth, M.J. Selective activation of anti-CD73 mechanisms in control of primary tumors and metastases. Oncoimmunology 2017, 6, e1312044. [CrossRef]

333. Vaupel, P.; Multhoff, G. Accomplices of the Hypoxic Tumor Microenvironment Compromising Antitumor Immunity: Adenosine, Lactate, Acidosis, Vascular Endothelial Growth Factor, Potassium Ions, and Phosphatidylserine. Front. Immunol. 2017, 8, 1887. [CrossRef] 
334. Gaspar, H.B.; Aiuti, A.; Porta, F.; Candotti, F.; Hershfield, M.S.; Notarangelo, L.D. How I treat ADA deficiency. Blood 2009, 114, 3524-3532. [CrossRef]

335. Allard, B.; Turcotte, M.; Spring, K.; Pommey, S.; Royal, I.; Stagg, J. Anti-CD73 therapy impairs tumor angiogenesis. Int. J. Cancer 2014, 134, 1466-1473. [CrossRef]

336. Koszalka, P.; Golunska, M.; Stanislawowski, M.; Urban, A.; Stasilojc, G.; Majewski, M.; Wierzbicki, P.; Skladanowski, A.C.; Bigda, J. CD73 on B16F10 melanoma cells in CD73-deficient mice promotes tumor growth, angiogenesis, neovascularization, macrophage infiltration and metastasis. Int. J. Biochem. Cell Biol. 2015, 69, 1-10. [CrossRef]

337. Garcia-Morales, L.J.; Chen, N.Y.; Weng, T.; Luo, F.; Davies, J.; Philip, K.; Volcik, K.A.; Melicoff, E.; Amione-Guerra, J.; Bunge, R.R.; et al. Altered Hypoxic-Adenosine Axis and Metabolism in Group III Pulmonary Hypertension. Am. J. Respir. Cell Mol. Biol. 2016, 54, 574-583. [CrossRef]

(C) 2019 by the authors. Licensee MDPI, Basel, Switzerland. This article is an open access article distributed under the terms and conditions of the Creative Commons Attribution (CC BY) license (http://creativecommons.org/licenses/by/4.0/). 